\title{
Linking phytochemistry to traditional uses and pharmacology of an underexplored genus - Psydrax: a review
}

\author{
Uche Maryann Chukwudulue • Alfred Francis Attah • \\ Festus Basden Chiedu Okoye
}
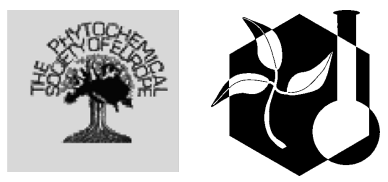

Received: 13 May 2021 / Accepted: 20 December 2021/Published online: 4 January 2022

(C) The Author(s), under exclusive licence to Springer Nature B.V. 2022

\begin{abstract}
The genus Psydrax is one of the ethnomedicinally important genera of the Rubiaceae family which has only received a limited scientific attention, despite coming from a pharmacologically and phytochemically important plant family. The genus has found applications in ethnomedical management of diabetes, stomach disorders, inflammations, cardiovascular diseases, epilepsy, wounds, malaria and fever. To unveil knowledge gaps, stimulate research interest and unravel opportunities for drug discovery from the genus Psydrax, we have carried out an extensive review on its traditional applications, phytochemistry and pharmacology for the first time. Literature on these topics was obtained from Google Scholar, Pubmed and ScienceDirect journal articles published from 1788 to September, 2021. Only articles
\end{abstract}

U. M. Chukwudulue

Department of Pharmaceutical and Medicinal Chemistry, Faculty of Pharmaceutical Sciences, Chukwuemeka Odumegwu Ojukwu University, Igbariam,

Anambra State, Nigeria

U. M. Chukwudulue · F. B. C. Okoye ( $\square)$

Department of Pharmaceutical and Medicinal Chemistry, Faculty of Pharmaceutical Sciences, Nnamdi Azikiwe

University, Awka, Anambra State, Nigeria

e-mail: fb.okoye@unizik.edu.ng

A. F. Attah ( $\square)$

Department of Pharmacognosy and Drug Development, Faculty of Pharmaceutical Sciences, University of Ilorin, Ilorin, Kwara State, Nigeria

e-mail: attah.fau@unilorin.edu.ng written in English were reviewed. While several species of Pysdrax used in traditional medicine have not been chemically explored for drug discovery, over a hundred secondary metabolites have so far been identified in few species of the genus, and majority of these chemotaxonomic markers are iridoids. Bioactive extracts and some isolated constituents of Psydrax species have shown various in vitro and in vivo pharmacological properties including anti-hyperglycemia, anti-inflammatory, anticonvulsant and antimicrobial, and thus, support some of the ethnomedical uses of the plants. For an evidenceinformed application of the genus, Psydrax, in traditional medicine, more ethnobotanical surveys, elaborate in vivo pharmacological assays, in-depth toxicity and holistic phytochemical studies are required to fully exploit more species of the genus prior to future clinical studies. Following documented traditional uses of Psydrax species, the deliberate cultivation of medicinal plants under this genus is recommended for sustainability in medicinal plant utilization.

Keywords Psydrax - Phytochemistry · Ethnopharmacology · Traditional medicine . Pharmacology 


\section{Introduction}

The Rubiaceae plant family has served as an important source of bioactive compounds and "leads" for drug discovery and development (Buathong et al. 2019; Koehbach et al. 2013; Maldonado et al. 2017; Wijnsma and Verpoorte 1986). While other genera within the Rubiaceae family have received considerable research attention as well as reviews on their species (Fan et al. 2020; Gibbons 2020; Heitzman et al. 2005; Kala 2015; Taher et al. 2020) which has stimulated further research, Psydrax genus has been underexplored scientifically; the genus has not been previously reviewed to reveal knowledge gaps and provide opportunities for further studies.

The genus name, Psydrax Gaertn., originally introduced, in 1788, by Joseph Gaertner in his book (Gaertner 1788) was abandoned until A. Richard included it in one of his papers in 1830, and was later reinstated by Bridson in 1985 (Bridson 1985). It belongs to the Vanguerieae tribe of the Rubiaceae family and is subdivided into two subgenera, the palaeotropical subgenus Psydrax, which exists as trees, shrubs or sometimes as scandent, and the African subgenus Phallaria, which exists as lianas or scandent shrubs (Bridson 1986, 1985). In this review, the common name Psydrax, would be adopted for the two subgenera, Phallaria and Psydrax. The full lineage of the genus, according to the NCBI taxonomy database, is shown in Table 1.

While Psydrax is known to be monophyletic (Bremer 2009; Lantz and Bremer 2004), with defined morphological characters, it still shares most of its characters with Keetia (Bridson 1985; Lantz et al. 2002; Lantz and Bremer 2004), which is a closely related genus also transferred from Canthium) and its circumscription is somehow problematic, with species more readily added to it (Davis et al. 2007). However, the Southern African Canthium s. str. (the remaining part of Canthium after the reinstatement of Psydrax and Keetia) and Psydrax can be distinguished distinctively by the anatomical features of their leaves and young stems (Tilney et al. 1990, 1988), while Keetia can be distinguished morphologically from Psydrax by its pyrene, anther and carlyx-limb (Bridson 1986; Lantz et al. 2002). Psydrax species go with varying synonyms which are adopted by different authors, and their number keeps increasing as new species, which are yet to be included in The Plant List database, are
Table 1 Taxonomic Ranking of Psydrax

\begin{tabular}{ll}
\hline Rank & Name \\
\hline No Rank & Cellular Organisms \\
Superkingdom & Eukaryota \\
Kingdom & Viridiplantae \\
Phylum & Streptophyta \\
Subphylum & Streptophytina \\
Clade & Embryophyta \\
Clade & Tracheophyta \\
Clade & Euphyllophyta \\
Clade & Spermatophyte \\
Class & Magnoliopsida \\
Clade & Mesangiospermae \\
Clade & Eudicotyledons \\
Clade & Gunneridae \\
Clade & Pentapetalae \\
Clade & Asterids \\
Clade & Lamiids \\
Order & Gentianales \\
Family & Rubiaceae \\
Subfamily & Ixoroideae \\
Tribe & Vanguerieae \\
Genus & Psydrax \\
\hline
\end{tabular}

being discovered (Arriola and Alejandro 2013; Arriola et al. 2017; Mahyuni et al. 2019). In 2020, a new species, $P$. gialaiensis, was discovered in Gia Lai Province, Southern Vietnam (Quang et al. 2020) and has been uploaded on the website of the World Checklist of Selected Plant Families(WCSP) alongside another new species, Psydrax lanceolatus.

As the largest and widest geographically distributed genus of Vanguerieae tribe (Lantz et al. 2002; Lantz and Bremer 2004), Psydrax is reportedly found in three continents, Africa, Asia and Oceania. According to the WCSP (wcsp.science.kew.org), accessed on 22 September, 2021, 130 species are included in the genus, as listed with their continental distributions in Table 2. However, two species, $P$. horizontale and $P$. hullensis, were missing in WCSP database, but were included in Tropicos and The Plant List databases, and eight names out of the 130 species' names in the WCSP database were unaccepted. Bridson and other group of researchers (Bridson 1985; Lantz et al. 2002) reported that more than thirty species of the genus are 
Table 2 A list of species in Psydrax genus compiled from World Checklist of Selected Plant Families (WCSP) and The Plant List databases

\begin{tabular}{|c|c|c|c|c|}
\hline $\begin{array}{l}\mathrm{S} / \\
\mathrm{N}\end{array}$ & Species & Author & $\begin{array}{l}\text { Date of } \\
\text { discovery }\end{array}$ & $\begin{array}{l}\text { Continental } \\
\text { distribution }\end{array}$ \\
\hline 1 & Psydrax acutiflora & (Hiern) Bridson & 1985 & Africa \\
\hline 2 & Psydrax ammophilus & S.T. Reynolds \& R.J.F. Hend & 2004 & Oceania \\
\hline 3 & Psydrax amplifolius & (Elmer) A.P. Davis & 2008 & Asia \\
\hline 4 & Psydrax angustifolius & A. Rich. ex DC & 1830 & \\
\hline 5 & Psydrax ankotekonensis & (Cavaco) A.P. Davis \& Bridson & 2007 & Africa \\
\hline 6 & Psydrax approximates & (Korth.) Mahyuni \& K.M. Wong & 2018 & Asia \\
\hline 7 & Psydrax arnoldianus & (De Wild. \& T. Durand) Bridson & 1985 & Africa \\
\hline 8 & Psydrax attenuatus & $\begin{array}{l}\text { (R. Br. ex Benth.) S.T. Reynolds \& R.J.F. } \\
\text { Hend }\end{array}$ & 2004 & Oceania \\
\hline 9 & Psydrax attenuatus var. attenuatus & & & Oceania \\
\hline 10 & Psydrax attenuatus fo. megalanthus & S.T. Reynolds \& R.J.F. Hend & 2004 & Oceania \\
\hline 11 & Psydrax attenuatus fo. myrmecophilus & S.T. Reynolds \& R.J.F. Hend & 2004 & \\
\hline 12 & $\begin{array}{l}\text { Psydrax attenuatus var. } \\
\text { myrmecophilus }\end{array}$ & S.T. Reynolds \& R.J.F. Hend & 2004 & Oceania \\
\hline 13 & Psydrax attenuata var. tenellus & S.T. Reynolds \& R.J.F. Hend & 2004 & Oceania \\
\hline 14 & Psydrax austro-orientalis & (Cavaco) A.P. Davis \& Bridson & 2007 & Africa \\
\hline 15 & Psydrax banksii & S.T. Reynolds \& R.J.F. Hend & 2004 & Oceania \\
\hline 16 & Psydrax bathieanus & (Cavaco) A.P. Davis \& Bridson & 2007 & Africa \\
\hline 17 & Psydrax bridsonianus & Cheek \& Sonké & 2004 & Africa \\
\hline 18 & Psydrax calcicola & (Craib) A.P. Davis & 2008 & Asia \\
\hline 19 & Psydrax capensis & J.C. Manning \& Golblatt & & Africa \\
\hline 20 & Psydrax connatus & De Wild. \& T. Durand & 1900 & \\
\hline 21 & Psydrax cymiger & (Valeton) S.T. Reynolds \& R.J.F. Hend & 2004 & Oceania \\
\hline 22 & Psydrax dicoccos & Gaertn & 1788 & Asia \\
\hline 23 & Psydrax dicoccos var. dicoccos & & & Asia \\
\hline 24 & Psydrax dicoccos var. lanceolatus & (Arn.) Ridsdale & 1996 & Asia \\
\hline 25 & Psydrax dicoccos var. obovatifolius & (G.A.Fu) Lantz & 2011 & Asia \\
\hline 26 & Psydrax dunlapii & (Hutch. \& Dalziel) Bridson & 1985 & Africa \\
\hline 27 & Psydrax esirensis & (Cavaco) A.P. Davis \& Bridson & 2007 & Africa \\
\hline 28 & Psydrax fasciculatus & (Blume) A.P. Davis & 2008 & Asia \\
\hline 29 & Psydrax faulknerae & Bridson & 1985 & Africa \\
\hline 30 & Psydrax ficiformis & (Hook. f.) Bridson & 1993 & Asia \\
\hline 31 & Psydrax forsteri & S.T. Reynolds \& R.J.F. Hend & 2004 & Oceania \\
\hline 32 & Psydrax fragrantissimus & (K.Schum) Bridson & 1985 & Africa \\
\hline 33 & Psydrax gialaiensis & B.H. Quang, T.B. Tran \&V.S. Dang & 2020 & Asia \\
\hline 34 & Psydrax gilletii & (De Wild.) Bridson & 1985 & Africa \\
\hline 35 & Psydrax glaber & (Blume) Deb \& M. Gangop & 2012 & \\
\hline 36 & Psydrax graciliflorus & $\begin{array}{l}\text { (Merr. \& L.M. Perry) S.T. Reynolds \& } \\
\text { R.J.F. Hend }\end{array}$ & 2004 & Oceania \\
\hline 37 & Psydrax grandifolius & (Thwaites) Ridsdale & 1996 & Asia \\
\hline 38 & Psydrax graniticola & (Chiov.) Bridson & 1985 & Africa \\
\hline 39 & Psydrax gynochthodes & $\begin{array}{l}\text { (Baill.) Arriola, Axel H., Alejandro \& } \\
\text { Yayen }\end{array}$ & 2014 & Asia \\
\hline 40 & Psydrax horizontalis & (Schumach.) Bridson & 1985 & Africa \\
\hline
\end{tabular}


Table 2 continued

\begin{tabular}{|c|c|c|c|c|}
\hline $\begin{array}{l}\mathrm{S} / \\
\mathrm{N}\end{array}$ & Species & Author & $\begin{array}{l}\text { Date of } \\
\text { discovery }\end{array}$ & $\begin{array}{l}\text { Continental } \\
\text { distribution }\end{array}$ \\
\hline 41 & Psydrax johnsonii & S.T. Reynolds \& R.J.F. Hend & 2004 & Oceania \\
\hline 42 & Psydrax kaessneri & (S. Moore) Bridson & 1985 & Africa \\
\hline 43 & Psydrax kibuwae & Bridson & 1985 & Africa \\
\hline 44 & Psydrax kingii & (Hook. f.) Bridson \& Springate & 1996 & Asia \\
\hline 45 & Psydrax kraussioides & (Hiern) Bridson & 1985 & Africa \\
\hline 46 & Psydrax lamprophyllus & (F. Muell.) Bridson & 1985 & Oceania \\
\hline 47 & $\begin{array}{l}\text { Psydrax lamprophyllus fo. } \\
\text { lamprophyllus }\end{array}$ & & & Oceania \\
\hline 48 & Psydrax lamprophyllus fo. Latissimus & S.T. Reynolds \& R.J.F. Hend & 2004 & Oceania \\
\hline 49 & Psydrax lanceolatus & (Arn.) R.Kr. Singh \& Arigela & 2020 & Asia \\
\hline 50 & Psydrax latifolius & $\begin{array}{l}\text { (F. Muell. ex Benth.) S.T. Reynolds \& } \\
\text { R.J.F. Hend }\end{array}$ & 2004 & Oceania \\
\hline 51 & Psydrax laxiflorens & S.T. Reynolds \& R.J.F. Hend & 2004 & Oceania \\
\hline 52 & Psydrax lepidus & S.T. Reynolds \& R.J.F. Hend & 2004 & Oceania \\
\hline 53 & Psydrax lividus & (Hiern) Bridson & 1985 & Africa \\
\hline 54 & Psydrax locuples & Bridson & 1985 & Africa \\
\hline 55 & Psydrax longipes & S.T. Reynolds \& R.J.F. Hend & 2004 & Oceania \\
\hline 56 & Psydrax longistylus & (Merr.) A.P. Davis & 2008 & Asia \\
\hline 57 & Psydrax lucidulus & (Miq.) Mahyuni \& K.M. Wong & 2018 & Asia \\
\hline 58 & Psydrax lynesii & Bridson & 1985 & Africa \\
\hline 59 & Psydrax maingayi & (Hook. f.) Bridson & 1985 & Asia \\
\hline 60 & Psydrax majus & A. Rich & 1830 & \\
\hline 61 & Psydrax manambyana & (Cavaco) A.P. Davis \& Bridson & 2007 & Africa \\
\hline 62 & Psydrax manensis & (Aubrév. \& Pellegr.) Bridson & 1985 & Africa \\
\hline 63 & Psydrax martini & (Dunkley) Bridson & 1985 & Africa \\
\hline 64 & Psydrax medius & A. Rich. ex DC & 1830 & \\
\hline 65 & Psydrax micans & (Bullock) Bridson & 1985 & Africa \\
\hline 66 & Psydrax moandensis & Bridson & 1985 & Africa \\
\hline 67 & Psydrax moggii & Bridson & 1985 & Africa \\
\hline 68 & Psydrax montanus & (Thwaites) Ridsdale & 1996 & Asia \\
\hline 69 & Psydrax montigenus & S.T. Reynolds \& R.J.F. Hend & 2004 & Oceania \\
\hline 70 & Psydrax multiflorus & Arriola, Axel H. \& Alejandro & 2017 & Asia \\
\hline 71 & Psydrax mutimushii & Bridson & 1985 & Africa \\
\hline 72 & $\begin{array}{l}\text { Psydrax mutimushii subsp. } \\
\text { mutimushii }\end{array}$ & & & Africa \\
\hline 73 & Psydrax mutimushii subsp. wagemansii & Bridson & 1985 & Africa \\
\hline 74 & Psydrax nitidus & (Craib) K.M. Wong & 1989 & Asia \\
\hline 75 & Psydrax obovatus & (Klotzsch ex Eckl. \& Zeyh.) Bridson & 1985 & Africa \\
\hline 76 & Psydrax obovatus subsp. ellipticus & Bridson & 1985 & Africa \\
\hline 77 & Psydrax obovatus subsp. obovatus & & & Africa \\
\hline 78 & Psydrax occidentalis & (Cavaco) A.P. Davis \& Bridson & 2007 & Africa \\
\hline 79 & Psydrax odoratus & (G. Forst.) A.C. Sm. \& S.P. Darwin & 1988 & Oceania \\
\hline 80 & Psydrax odorata subsp. arnhemicus & S.T. Reynolds \& R.J.F. Hend & 2004 & Oceania \\
\hline 81 & Psydrax odoratus fo. Australianus & S.T. Reynolds \& R.J.F. Hend & 2004 & \\
\hline 82 & Psydrax odoratus subsp. australianus & S.T. Reynolds \& R.J.F. Hend & 2004 & Oceania \\
\hline
\end{tabular}


Table 2 continued

\begin{tabular}{|c|c|c|c|c|}
\hline $\begin{array}{l}\mathrm{S} / \\
\mathrm{N}\end{array}$ & Species & Author & $\begin{array}{l}\text { Date of } \\
\text { discovery }\end{array}$ & $\begin{array}{l}\text { Continental } \\
\text { distribution }\end{array}$ \\
\hline 83 & Psydrax odoratus fo. Buxifolius & (Benth.) S.T. Reynolds \& R.J.F. Hend & 2004 & Oceania \\
\hline 84 & Psydrax odoratus subsp. buxifolius & (Benth.) S.T. Reynolds & 2004 & Oceania \\
\hline 85 & Psydrax odoratus fo. Foveolatus & S.T. Reynolds \& R.J.F. Hend & 2004 & Oceania \\
\hline 86 & Psydrax odoratus subsp. odoratus & & & Oceania \\
\hline 87 & Psydrax odoratus fo. Parviflorifer & S.T. Reynolds \& R.J.F. Hend & 2004 & Oceania \\
\hline 88 & Psydrax odoratus fo. Subnitidus & S.T. Reynolds \& R.J.F. Hend & 2004 & Oceania \\
\hline 89 & Psydrax oleifolius & (Hook.) S.T. Reynolds \& R.J.F. Hend & 2004 & Oceania \\
\hline 90 & Psydrax pallidus & S.T. Reynolds \& R.J.F. Hend & 2004 & Oceania \\
\hline 91 & Psydrax palma & (K. Schum.) Bridson & 1985 & Africa \\
\hline 92 & Psydrax paludosus & S.T. Reynolds \& R.J.F. Hend & 2004 & Oceania \\
\hline 93 & Psydrax paradoxus & (Virot) Mouly & 2006 & Oceania \\
\hline 94 & Psydrax parviflorus & (Afzel.) Bridson & 1985 & Africa \\
\hline 95 & Psydrax parviflorus subsp. chapmanii & Bridson & 1985 & Africa \\
\hline 96 & $\begin{array}{l}\text { Psydrax parviflorus subsp. } \\
\text { melanophengos }\end{array}$ & (Bullock) Bridson & 1985 & Africa \\
\hline 97 & Psydrax parviflorus subsp. parviflorus & & & Africa \\
\hline 98 & $\begin{array}{l}\text { Psydrax parviflorus subsp. } \\
\text { rubrocostatus }\end{array}$ & (Robyns) Bridson & 1985 & Africa \\
\hline 99 & Psydrax pendulinus & S.T. Reynolds \& R.J.F. Hend & 2004 & Oceania \\
\hline 100 & Psydrax pergracilis & (Bourd.) Ridsdale & 1996 & Asia \\
\hline 101 & Psydrax polhillii & Bridson & 1985 & Africa \\
\hline 102 & Psydrax puberula & Arriola \& Alejandro & 2013 & Asia \\
\hline 103 & Psydrax recurvifolius & (Bullock) Bridson & 1985 & Africa \\
\hline 104 & Psydrax reticulatus & (C.T. White) S.T. Reynolds \& R.J.F. Hend & 2004 & Oceania \\
\hline 105 & Psydrax richardsiae & Bridson & 1985 & Africa \\
\hline 106 & Psydrax rigidulus & S.T. Reynolds \& R.J.F. Hend & 2004 & Oceania \\
\hline 107 & Psydrax robertsoniae & Bridson & 1991 & Africa \\
\hline 108 & Psydrax sabahensi & Mahyuni & 2019 & Asia \\
\hline 109 & Psydrax salignus & S.T. Reynolds \& R.J.F. Hend & 2004 & Oceania \\
\hline 110 & Psydrax salignus fo. Filiformis & S.T. Reynolds \& R.J.F. Hend & 2004 & Oceania \\
\hline 111 & Psydrax salignus fo. Salignus & & & Oceania \\
\hline 112 & Psydrax sambiranensis & (Cavaco) A.P. Davis \& Bridson & 2007 & Africa \\
\hline 113 & Psydrax schimperianus & (A. Rich.) Bridson & 1985 & Africa and Asia \\
\hline 114 & $\begin{array}{l}\text { Psydrax schimperianus subsp. } \\
\text { Occidentalis }\end{array}$ & Bridson & 1985 & Africa \\
\hline 115 & $\begin{array}{l}\text { Psydrax schimperianus subsp. } \\
\text { schimperianus }\end{array}$ & & & Africa and Asia \\
\hline 116 & Psydrax sepikensis & A.P. Davis & 2008 & Oceania \\
\hline 117 & Psydrax shuguriensis & Bridson & 1985 & Africa \\
\hline 118 & Psydrax splendens & (K. Schum.) Bridson & 1985 & Africa \\
\hline 119 & Psydrax suaveolens & (S. Moore) S.T. Reynolds \& R.J.F. Hend & 2004 & Oceania \\
\hline 120 & Psydrax subcordatus & (DC.) Bridson & 1985 & Africa \\
\hline 121 & Psydrax subcordata var. connatus & (De Wild. \& T. Durand) Bridson & 1985 & Africa \\
\hline 122 & Psydrax subcordatus var. subcordatus & & & Africa \\
\hline 123 & Psydrax suborbicularis & (C.T. White) S.T. Reynolds \& R.J.F. Hend & 2004 & Oceania \\
\hline
\end{tabular}


Table 2 continued

\begin{tabular}{|c|c|c|c|c|}
\hline $\begin{array}{l}\mathrm{S} / \\
\mathrm{N}\end{array}$ & Species & Author & $\begin{array}{l}\text { Date of } \\
\text { discovery }\end{array}$ & $\begin{array}{l}\text { Continental } \\
\text { distribution }\end{array}$ \\
\hline 124 & P. sumatranus & (Miq.) Mahyuni & 2018 & Asia \\
\hline 125 & Psydrax tropicus & S.T. Reynolds \& R.J.F. Hend & 2004 & Oceania \\
\hline 126 & Psydrax umbellatus & (Wight) Bridson & 1993 & Asia \\
\hline 127 & Psydrax undulatifolius & K.M. Wong \& Mahyuni & 2018 & Asia \\
\hline 128 & Psydrax virgatus & (Hiern) Bridson & 1985 & Africa \\
\hline 129 & Psydrax whitei & Bridson & 1985 & Africa \\
\hline 130 & Psydrax wongii & Mahyuni & 2019 & Asia \\
\hline
\end{tabular}

Names in bold imply presence in both The Plant List and WCSP databases, while names in plain imply presence only in WCSP

native to Africa, and these are not far from the WCSP's list of continental distribution of 54 species of the genus in different countries in Africa. Though, Psydrax is the largest genus in its tribe, some of its species are rare and at the verge of extinction (Cheek and Sonké 2004; Subashree et al. 2021), and their decreasing population may be ascribed to their traditional uses (Arriola et al. 2017; Tabuti et al. 2009, 2011).

Surprisingly, only about $8 \%$ of Psydrax species have been reported for their ethnomedicinal uses and pharmacological activities, with $P$. subcordata (DC.) Bridson having the highest coverage. In other words, close to $92 \%$ of this genus have not received scientific attention beginning from documentation of local knowledge on the genus via ethnopharmacological surveys, and the ethnomedicinal application of species within this genus in meeting primary healthcare needs. Across Africa, different parts of $P$. subcordata (DC.) Bridson are used in the treatment of varied health issues such as cardiovascular diseases, inflammation, stomach disorder, epilepsy, malaria and fever (Awah et al. 2012; Awantu et al. 2019; Chukwujekwu et al. 2005; Daanaa et al. 2018). P. dicoccos, found mostly in Asia, is used in folk medicine for rheumatoid pains and asthma (Kalaichelvi and Dhivya 2016; Neelima et al. 2011). Psydrax species have also found applications in ethnoveterinary medicine as wound healing and antiparasitic agents, in the treatment of ectoparasites, and as piscicide in fish farming (Maroyi 2012; Mukandiwa et al. 2012a, b; Nyahangare et al. 2015; Raja et al. 2011).
Phytochemical screening of few of the Psydrax species revealed that the major phytochemical class in these plants is the iridoid. Interestingly, iridoids have been reported to possess a number of pharmacological and biological activities, such as antimalarial, antidiabetic, antioxidant, antitumor, antibacterial, antiviral, anti-inflammatory, neuroprotective and cardioprotective effects (Ghisalberti 1998; Tundis et al. 2008). Plants rich in iridoids are also useful antidotes against arthritis, diabetes, tumor, fever, wounds, hypertension and other health conditions (Dinda 2019). Other secondary metabolites have also been identified in Psydrax including alkaloids, flavonoids and other terpenoids, and few pharmacological studies have been conducted to link the traditional uses of few species in this genus to the identified phytochemical contents.

This article reviews the ethnopharmacological uses, phytochemistry, and pharmacological properties of Psydrax genus from 1788 to September, 2021. The literature search was carried out using Google Scholar, PubMed and ScienceDirect digital repositories following the varied combination of these words: Rubiaceae, Psydrax, Canthium, "Traditional uses", "folkloric medicine", ethnopharmacology, bioactivities, "biological activities", "pharmacological properties", phytochemistry, "phytochemical constituents", phytochemicals. Only peer-reviewed articles written in english language were used by authors with the overall aim to inspire further studies on the genus, Psydrax, particularly its underexplored species. 
Table 3 Ethnomedicinal applications of Psydrax species in Africa, Asia and Oceania

\begin{tabular}{|c|c|c|c|c|c|}
\hline Species & $\begin{array}{l}\text { Part } \\
\text { Used }\end{array}$ & $\begin{array}{l}\text { Method of Preparation } \\
\text { (Administration) }\end{array}$ & Uses & Country & References \\
\hline \multirow[t]{11}{*}{ P. subcordata } & SB & Alcoholic extract (NS) & Diabetes & NS & (Achenbach et al. 1981) \\
\hline & \multirow[t]{3}{*}{ SB } & Decoction (NS) & $\begin{array}{l}\text { Haemorrhoids, Stomach } \\
\text { ulcer }\end{array}$ & \multirow[t]{3}{*}{ Ghana } & (Agyare et al. 2009) \\
\hline & & Paste (Oral) & Body pains & & \multirow[t]{2}{*}{ (Appiah et al. 2018) } \\
\hline & & Paste (Topical) & Boils & & \\
\hline & NS & NS (NS) & Epilepsy & Cote d'Ivoire & (Daanaa et al. 2018) \\
\hline & $\mathrm{R}$ & \multirow[t]{2}{*}{ Aqueous extract (Oral) } & Malaria & \multirow[t]{4}{*}{ Nigeria } & \multirow[t]{2}{*}{ (Chukwujekwu et al. 2005) } \\
\hline & SB & & Fever & & \\
\hline & $\mathrm{R}$ & NS (NS) & Fever & & (Awah et al. 2012) \\
\hline & & & $\begin{array}{l}\text { Malaria, Inflammation, } \\
\text { Cardiovascular diseases }\end{array}$ & & \\
\hline & WP & NS (NS) & Stomach disorders & Cameroon & (Awantu et al. 2019) \\
\hline & $\mathrm{B}$ & Extract (NS) & High blood pressure & NS & (Achenbach 1986) \\
\hline \multirow[t]{4}{*}{ P. livida } & Fr & Raw (Oral) & Food & South Africa & (Magwede et al. 2018) \\
\hline & \multirow[t]{2}{*}{$\mathrm{L}$} & \multirow[t]{2}{*}{ Paste (Topical) } & Wounds in livestock & $\begin{array}{l}\text { Zimbabwe } \\
\text { South Africa }\end{array}$ & $\begin{array}{l}\text { (Maroyi 2012; Mukandiwa } \\
\text { et al. 2012a, b) }\end{array}$ \\
\hline & & & Ecto-parasites in livestock & Zimbabwe & (Nyahangare et al. 2015) \\
\hline & $\mathrm{R}$ & NS (NS) & $\begin{array}{l}\text { Fever associated with } \\
\text { malaria }\end{array}$ & Namibia & (du Preez et al. 2020) \\
\hline P. acutiflora & AP & NS (NS & Malaria & Burkina Faso & (Ilboudo et al. 2013) \\
\hline \multirow[t]{3}{*}{ P. parviflora } & $\mathrm{B}$ & NS (NS) & Pains & Guinea-Bissau & (Catarino et al. 2016) \\
\hline & \multicolumn{3}{|l|}{$\mathrm{L}$} & & \\
\hline & $\mathrm{RB}$ & Decoction (Oral) & Infectious diseases & Guinea & (Magassouba et al. 2007) \\
\hline P. horizontalis & $\mathrm{L}$ & NS (NS) & Diabetes & Nigeria & (Feenna et al. 2020) \\
\hline \multirow[t]{4}{*}{$\begin{array}{l}P . \\
\text { schimperiana }\end{array}$} & SB & $\begin{array}{l}\text { Decoction (Oral) } \\
\text { Paste (Topical) }\end{array}$ & Breast cancer & Kenya & $\begin{array}{l}\text { (Ochwang'i et al. } \\
\text { 2014, 2018) }\end{array}$ \\
\hline & \multirow[t]{2}{*}{$\mathrm{L}$} & Cold infusion (Oral) & Stomachache & \multirow[t]{3}{*}{ Ethiopia } & (Radol et al. 2016) \\
\hline & & Paste (NS) & Snake bite & & (Asfaw et al. 2021) \\
\hline & Fr & Raw (Oral) & Food & & (Gemedo-Dalle et al. 2005) \\
\hline \multirow[t]{7}{*}{ P. dicoccos } & \multirow[t]{3}{*}{$\mathrm{L}$} & $\begin{array}{l}\text { Extract and banana } \\
\quad(\text { Oral })\end{array}$ & Easy delivery & \multirow[t]{9}{*}{ India } & (Vaidyanathan et al. 2013) \\
\hline & & NS (NS) & Pain relief & & $\begin{array}{l}\text { (Chandramouli and } \\
\text { Mallikarjuna 2020) }\end{array}$ \\
\hline & & Decoction (NS) & $\begin{array}{l}\text { Fever, cough, asthma and } \\
\text { inflammation }\end{array}$ & & $\begin{array}{l}\text { (Kalaichelvi and Dhivya } \\
\text { 2016) }\end{array}$ \\
\hline & $\mathrm{F}$ & Raw (Oral) & Food & & (Rasingam 2012) \\
\hline & $\mathrm{B}$ & $\begin{array}{l}\text { Boil in sesame oil } \\
\text { (Topical) }\end{array}$ & Rheumatoid pains & & (Neelima et al. 2011) \\
\hline & $\begin{array}{c}\mathrm{L} B \\
\text { and } \\
\mathrm{R}\end{array}$ & NS (NS) & Piscicide & & $\begin{array}{l}\text { (Dutta et al. 2019; Kalita } \\
\text { et al. 2017) }\end{array}$ \\
\hline & $\mathrm{R}$ & Aqueous decoction/oral & Diarrhoea & & (Raja et al. 2011) \\
\hline \multirow[t]{2}{*}{ P. umbellata } & $\mathrm{L}$ & NS (NS) & Kidney, bladder diseases & & (Vijayashalini et al. 2017) \\
\hline & WP & NS (NS) & $\begin{array}{l}\text { Easy delivery, Uterus related } \\
\text { problems }\end{array}$ & & $\begin{array}{l}\text { (Pakkala and Patel 2021; } \\
\text { Ponnaiah et al. 2018) }\end{array}$ \\
\hline P. nitida & $\mathrm{L}$ & NS (NS) & Diarrhoea & Malaysia & (Eswani et al. 2010) \\
\hline
\end{tabular}


Table 3 continued

\begin{tabular}{llllll}
\hline Species & $\begin{array}{c}\text { Part } \\
\text { Used }\end{array}$ & $\begin{array}{l}\text { Method of Preparation } \\
\text { (Administration) }\end{array}$ & Uses & Country & References \\
\hline P. odorata & $\begin{array}{c}\text { B and } \\
\mathrm{L}\end{array}$ & NS(NS) & Cephalalgia and as purgative & $\begin{array}{c}\text { New } \\
\text { Caledonia }\end{array}$ & (Sévenet and Pusset 1996)
\end{tabular}

Plant parts used: AP: aerial parts; B: bark; Fr: fruit; L: leaves; R: root; RB: root bark; SB: stem bark; NS: not specified; WP: whole plant

Countries: NS: not specified

Method of preparation (Administration): NS: not specified

\section{Ethnopharmacology}

The few reported traditional uses of Psydrax species in different parts of Africa, Asia and Oceania and the forms in which they are used are summarized in Table 3. In some of the articles, there was no distinction between stem bark and root bark; the plant part was reported just as bark. Thus, if we take the bark, root bark and stem bark to be different, then the leaf becomes the most explored plant part of the genus in ethnomedicine with about $38 \%$ of the reviewed articles reporting leaves as the plant's part used in ethnomedicine preparations, either alone or in combination with other plant parts. The trend in popularity of other plant parts is as follows: bark (approx. 21\%), stem bark and root (approx. 17\% each), and whole plant and aerial parts (approx. 4\% each). The high popularity of the leaf of the genus in ethnomedicine is expected as the leaf is easily accessible and nondestructive of plant biodiversity (du Preez, Shingenge, and Mumbengegwi 2020). In the course of this review, it is observed that the popularity of Psydrax in traditional medicine is quite minimal when compared to other genus of the Rubiaceae family (Magassouba et al. 2007), and this could be due to the rarity of the Psydrax species. Also observable from some of the reports on the folkoric use of these plants is that the method of preparing and the route of administration of some of the herbal medicines were omitted and only one paper reported the fidelity level for the use of the genus in traditional medicine. These obscurities could impede future scientific investigations to confirm traditional claims for the genus.

Clearly seen in Table 3 is the fact that $P$. subcordata is the most widely used species of the genus in ethnomedicine. In Africa where P. subcordata is endemic, it is used in folkloric medicine in four specified and two unspecified African countries and this presents the species as the most popular species in African traditional medicine and Appiah and coworkers recorded a fidelity level of $50 \%$ for the use of stem bark preparation of $P$. subcordata in the treatment of boil in Ghana (Appiah et al. 2018). The next most popular species in African traditional medicine is $P$. livida, while in Asia, specifically in India, $P$. dicoccos is the most explored species. In Oceania, $P$. odorata is the only species reported and it is used traditionally as purgative. In the course of this review, it was observed that ethnomedicinal uses of some of these plant species were reported using their synonyms. For instance, P. subcordata, P. livida, $P$. acutiflora, $P$. dicoccos and $P$. odorata were reported as Canthium subcordatum, Canthium huillense, Canthium henriquesianum, Canthium dicoccus and Plectronia odorata, respectively.

In four specified African countries - Cameroon, Cote d'Ivoire, Ghana and Nigeria - different parts of $P$. subcordata have found applications in traditional management of some ailments including the management of stomach ulcer, haemorrhoids, body pains and boils using stem bark in Ghana, (Agyare et al. 2009; Appiah et al. 2018); the use of an unspecified part of the plant in the management of epilepsy in Cote d'Ivoire (Daanaa et al. 2018); the use of root and stem bark preparation in the treatment of fever and malaria in Nigeria (Chukwujekwu et al. 2005); the use of the root in the treatment malaria, fever, inflammation and cardiovascular diseases in Cameroon (Awah et al. 2012); the use of the whole plant in the management of stomach disorders in an unspecified African country 
(Awantu et al. 2019); and the use of the bark in the management of high-blood pressure (Achenbach 1986). It is always exciting to know that a plant species has medicinal values. However, if the activities of a plant are numerous and unrelated, it becomes a concern and requires conduction of thorough scientific investigations, including cytotoxicity assay and clinical trials, to ascertain the mechanism of action of that plant indicated for those disease conditions (Gertsch 2009). We therefore suggest that $P$. subcordata should be extensively investigated for its phytochemistry and pharmacological properties to confirm its multiple applications in folkloric medicine.

The less popular species in African traditional medicine are $P$. horizontalis whose leaves are used in the management of diabetes in Nigeria (Feenna et al. 2020); in Kenya, stem bark and leaves of P. schimperiana are used for the management of breast cancer and stomachache associated with HIV infection, respectively (Ochwang'i et al. 2014, 2018; Radol et al. 2016), while in Ethiopia, the fruit is consumed by humans as one of the edible wild fruits and the roots used for management of diarrhoea (Gemedo-Dalle et al. 2005); in Guinea-Bissau, barks and leaves of $P$. parviflora are used in treating pains (Catarino et al. 2016), while in Guinea the root bark decoction is used for infectious diseases (Magassouba et al. 2007); fruits of $P$. livida are consumed as edible fruits in South Africa (Magwede et al. 2018), while in Zimbabwe the leaf paste is popularly used for treating wounds (Maroyi 2012; Mukandiwa et al. 2012a, b) and ectoparasites in livestock (Nyahangare et al. 2015).

In Asia, different parts of $P$. dicoccos are widely used in Indian ethnomedicine for the treatment of a variety of ailment: the leaf preparations are used for general pain relief (Chandramouli and Mallikarjuna 2020), to ease delivery (Vaidyanathan et al. 2013), and to treat fever, cough, asthma and inflammation (Kalaichelvi and Dhivya 2016); the fruit is edible (Rasingam 2012); the bark powder preparation is used topically to treat rheumatic pains (Neelima et al. 2011); root decoction is used for the treatment of diarrhoea (Raja et al. 2011); the juice obtained from crushing together the leaf and bark is used to treat high blood pressure (Sen and Behera 2016); and in ethnoveterinary medicine, the leaves, bark and root of $P$. dicoccos are used as piscicides for controlling predatory fish species (Dutta et al. 2019; Kalita et al. 2017). The leaf extract of $P$. umbellata, is used for the treatment of urinary tract diseases (Dhivya and Kalaichelvi 2016; Vijayashalini et al. 2017). In Malaysia, an unspecified part of P. livida is used in the management of diarrhoea.

In Oceania, New Caledonia to be precise, a mixture of the bark and leaves of P. odorata is used for cephalalgia, and as a purgative in combination with other plants and sea water (Sévenet and Pusset 1996).

\section{Phytochemistry}

The few Psydrax species which have been screened for phytochemicals contain various chemical constituents such as saponins, terpenes, tannins, coumarins, glycosides and flavonoids (Akoto et al. 2019). Out of the over 100 species of the genus, only eight of the species including $P$. subcordata, $P$. acutiflora, $P$. montigena, $P$. livida, $P$. odorata, $P$. dicoccos, $P$. puberula and $P$. schimperiana have been explored for phytochemicals, and approximately 131 compounds were identified using different chromatographic and spectroscopic techniques. However, only the structures of fifty-five compounds (1-55) isolated from this genus and characterized using NMR and/or LC-MS techniques are given in this review. Their names are also listed in Table 4. About half of the 55 isolated compounds of this genus are iridoids (1-27), while the remaining $50 \%$ are other terpenes (28-35), cyanogenic glycosides (36-39), alkaloids (40-42) and others we called miscellaneous compounds (43-55) because they were too small to be grouped into classes. Twenty-one of the iridoids (1-21) were isolated from different parts (stem bark, fruit and leaf) of the moderately studied species of the genus, $P$. subcordata, with shanziside methyl ester (21) appearing in both the stem bark and the fruit extracts of the species. The other six iridoids (22-27) were obtained from $P$. montigena (22) and the leaf and bark of $P$. odorata (23-27). Since iridoid is the most commonly encountered non-volatile chemical constituent of the genus, we adjudge it as the chemotaxonomic marker of the genus and would focus our discussion of the phytochemical importance of Psydrax on iridoid.

The rest of the phytoconstituents of the genus listed in Table 4 are volatile compounds (56-131) which were identified by GC-MS analysis. They made up more than half (about 58\%) of the 131 phytochemicals of Psydrax. Forty-six of them (56-101) were identified 
Table 4 Chemical constituents of psydrax

Compounds characterized by NMR analysis

No Compound name

\begin{tabular}{|c|c|c|c|c|}
\hline & & & part & \\
\hline 1 & Cerbinal & P. subcordata & SB & (Awantu et al. 2019) \\
\hline 2 & Cerberinic acid & & & \\
\hline 3 & Subcordatanol I & P. subcordata & $\mathrm{L}$ and & (Zhou et al. 2019) \\
\hline 4 & Subcordatanol II & & B & \\
\hline 5 & Subcordatanol III & & & \\
\hline 6 & Subcordatanol IV & & & \\
\hline 7 & Subcordatanol V & & & \\
\hline 8 & 1-O- methylcrescentin I & & & \\
\hline 9 & 10-Deoxyeucommiol & & & \\
\hline 10 & $6 \beta$-Hydroxy-2-oxabicyclo[4.3.0] $\Delta^{8,9}$-nonen-1-one & & & \\
\hline 11 & Shanzhigenin methyl ester & P. subcordata & $\mathrm{Fr}$ & (Joubouhi et al. 2015, 2017) \\
\hline 12 & 1-Epishanzhigenin methyl ester & & & \\
\hline 13 & Linearin & & & \\
\hline 14 & 1-Epilinearin & & & \\
\hline 15 & Mussaenoside & & & \\
\hline 16 & Canthiumosides (1) & & & \\
\hline 17 & Canthiumosides (2) & & & \\
\hline 18 & Canthiumosides (3) & & & \\
\hline 19 & Canthiumosides (4) & & & \\
\hline 20 & Canthiumosides (5) & & & \\
\hline 21 & Shanziside methyl ester & P. subcordata & $\begin{array}{l}\text { SB } \\
\text { and } \\
\text { Fr }\end{array}$ & $\begin{array}{l}\text { (Achenbach et al. 1981; } \\
\text { Achenbach 1986; Joubouhi } \\
\text { et al. 2015, 2017) }\end{array}$ \\
\hline 22 & Arborside $\mathrm{E}^{*}$ & P. montigena & NS & (Yang et al. 2016) \\
\hline 23 & 6-O-benzoylshanzhiside methyl ester & P. odorata & $\mathrm{B}$ and & (Coulerie and Poullain 2016; \\
\hline 24 & 8-O-benzoylshanzhiside methyl ester & & $\mathrm{L}$ & Sévenet and Pusset 1996) \\
\hline 25 & 6-O-benzoyl-6'-O-acetylshanzhiside methyl ester & & & \\
\hline 26 & 6,6'-di-O-dibenzoylshanzhiside methyl ester & & & \\
\hline 27 & Shanzhisin methyl ester gentiobioside & & & \\
\hline 28 & $\beta$-sitosterol & P. subcordata & $\begin{array}{l}\text { SB } \\
\text { and } \\
\mathrm{L}\end{array}$ & $\begin{array}{l}\text { (Awantu et al. 2019; Castro } \\
\text { et al. 2016) }\end{array}$ \\
\hline 29 & Ursolic acid & P. subcordata & SB & (Awantu et al. 2019) \\
\hline 30 & Quinovic acid & & & \\
\hline 31 & Oleanolic acid & P. subcordata & Fr & (Joubouhi et al. 2015, 2017) \\
\hline 32 & Betulinic acid & & & \\
\hline 33 & Glucoside roseoside & P. subcordata & SB & $\begin{array}{l}\text { (Achenbach 1986; Achenbach } \\
\text { et al. 1981) }\end{array}$ \\
\hline 34 & 3-O- $\beta$-D-glucopyranosylquinovic acid & P. subcordata & SB & (Awantu et al. 2019) \\
\hline 35 & 3-O- $\beta$-D-glucopyranosyloleanolic acid & & & \\
\hline 36 & Prunasin & P. livida & $\mathrm{L}$ & (Rockenbach et al. 1992) \\
\hline 37 & Oxyanthin & P. livida & $\begin{array}{l}\text { Fr, L } \\
\text { and } \\
\mathrm{S}\end{array}$ & $\begin{array}{l}\text { (Rockenbach and Nahrstedt } \\
\text { 1990; Rockenbach et al. } \\
\text { 1992) }\end{array}$ \\
\hline
\end{tabular}


Table 4 continued

Compounds characterized by NMR analysis

\begin{tabular}{|c|c|c|c|c|}
\hline No & Compound name & Plant species & $\begin{array}{l}\text { Plant } \\
\text { part }\end{array}$ & References \\
\hline 38 & Oxyanthin 5''-O-benzoate & P. livida & $\mathrm{L}$ and & \\
\hline 39 & $\begin{array}{l}2 R \text {-[(2-Methoxybenzoylgenoposidyl)-5- } O \text { - } \beta \text {-D-apiofuranosyl- } \\
\quad(1 \rightarrow 6) \text { - } \beta \text {-glucopyranosyloxy }]-2 \text {-phenyl acetonitrile }\end{array}$ & $\begin{array}{l}P . \\
\text { schimperiana }\end{array}$ & Fr & (Schwarz et al. 1996) \\
\hline 40 & Plectrodorine & \multirow[t]{3}{*}{ P. odorata } & \multirow{3}{*}{ B and } & \multirow{3}{*}{$\begin{array}{l}\text { (Coulerie and Poullain 2016; } \\
\text { Sévenet and Pusset 1996) }\end{array}$} \\
\hline 41 & Iso-plectrodorine & & & \\
\hline 42 & N-Desmethylmyrianthine & & & \\
\hline 43 & 3',4',7-trihydroxyflavone & \multirow[t]{2}{*}{ P. subcordata } & \multirow[t]{2}{*}{$\mathrm{Fr}$} & \multirow[t]{2}{*}{ (Joubouhi et al. 2015, 2017) } \\
\hline 44 & Rutin & & & \\
\hline 45 & 7- $O$-(6- $O$-benzoyl- $\beta$-D-glucosyl)-rutin & P. dicoccos & $\mathrm{L}$ & (Gunasegaran et al. 2001) \\
\hline 46 & D-mannitol & \multirow[t]{4}{*}{ P. subcordata } & \multirow[t]{4}{*}{ SB } & \multirow{4}{*}{$\begin{array}{l}\text { (Achenbach 1986; Achenbach } \\
\text { et al. 1981) }\end{array}$} \\
\hline 47 & Orcinol rnonomethyl ether & & & \\
\hline 48 & Scopoletin & & & \\
\hline 49 & Indole & & & \\
\hline 50 & Chromone & P. acutiflora & $\begin{array}{l}\mathrm{L} \text { and } \\
\mathrm{Tw}\end{array}$ & (Ilboudo et al. 2013) \\
\hline 51 & Clemahexapetoside B & P. subcordata & SB & (Awantu et al. 2019) \\
\hline 52 & Psydrin & \multirow[t]{2}{*}{ P. livida } & \multirow[t]{2}{*}{$\mathrm{L}$} & \multirow[t]{2}{*}{ (Nahrstedt et al. 1995) } \\
\hline 53 & Psydroside & & & \\
\hline 54 & 3,5-dicaffeoylquinic acid & $P$. & $\mathrm{Fr}$ & (Schwarz et al. 1996) \\
\hline 55 & 3,4-dicaffeoylquinic acid & \multicolumn{2}{|l|}{ schimperiana } & \\
\hline
\end{tabular}

Compounds identified by GC-MS analysis

\begin{tabular}{|c|c|c|c|c|}
\hline 56 & (E)-2-Hexenal & $\begin{array}{l}P . \\
\text { subcordata }\end{array}$ & $\begin{array}{c}\text { Fr-E- } \\
\mathrm{O}\end{array}$ & $\begin{array}{l}\text { (Essien et al. } \\
\text { 2015) }\end{array}$ \\
\hline 57 & $\alpha$-Pinene & & & \\
\hline 58 & Benzaldehyde & & & \\
\hline 59 & 1-Octen-3-ol & & & \\
\hline 60 & 3-Octanol & & & \\
\hline 61 & $p$-Cymene & & & \\
\hline 62 & 1,8-Cineole & & & \\
\hline 63 & Linalool & & & \\
\hline 64 & Nonanol & & & \\
\hline 65 & Methyl salicylate & & & \\
\hline 66 & $\beta$-Cyclocitral & & & \\
\hline 67 & Thymol methyl ether & & & \\
\hline 68 & Geraniol & & & \\
\hline 69 & $\alpha$-Cubebene & & & \\
\hline 70 & $\beta$-Bourbonene & & & \\
\hline 71 & $\beta$-Cubebene & & & \\
\hline 72 & $\beta$-Elemene & & & \\
\hline 73 & Cyperene & & & \\
\hline 74 & $\alpha$-Gurjunene & & & \\
\hline 75 & $\beta$-Caryophyllene & & & \\
\hline 76 & Calarene & & & \\
\hline
\end{tabular}


Table 4 continued

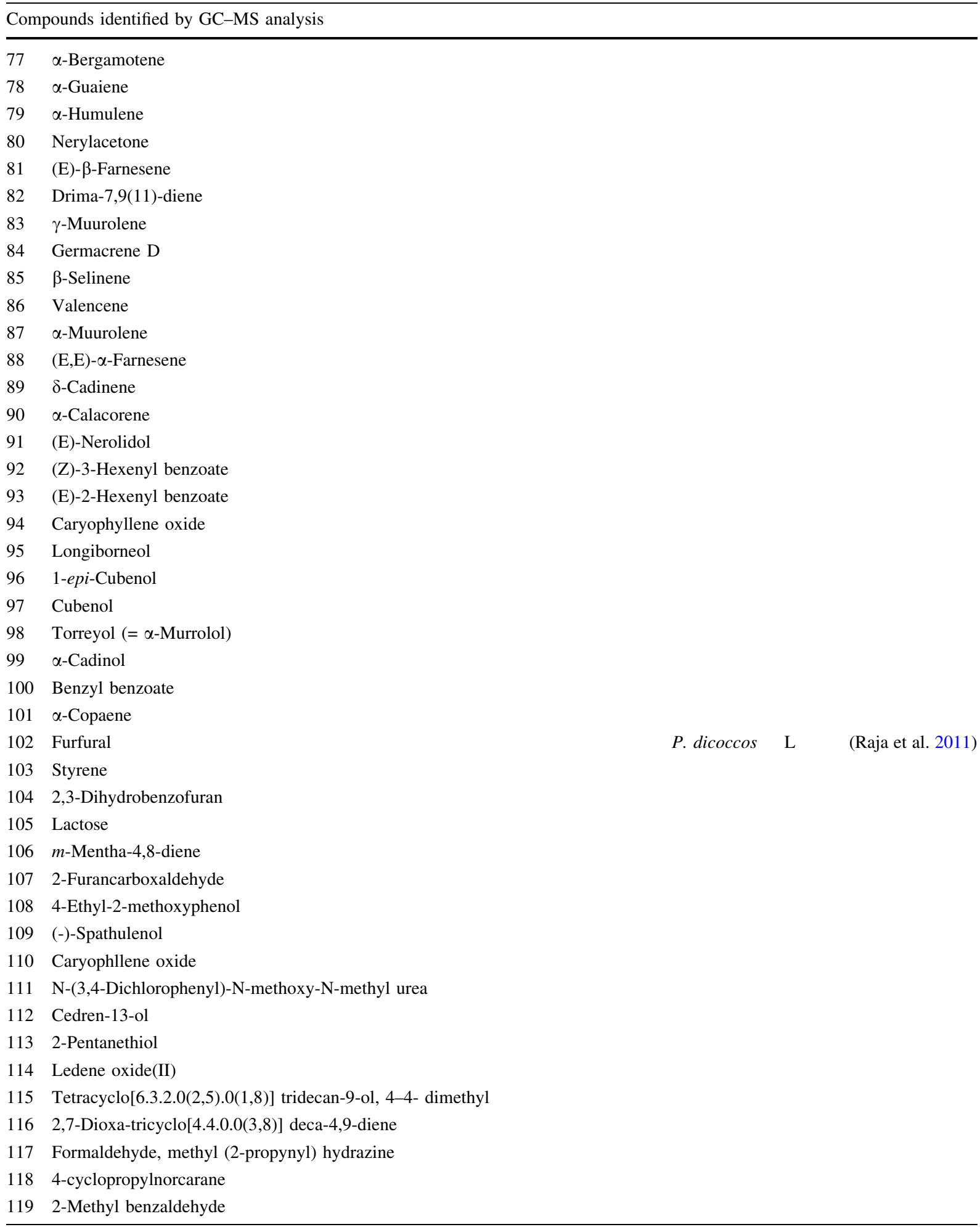


Table 4 continued

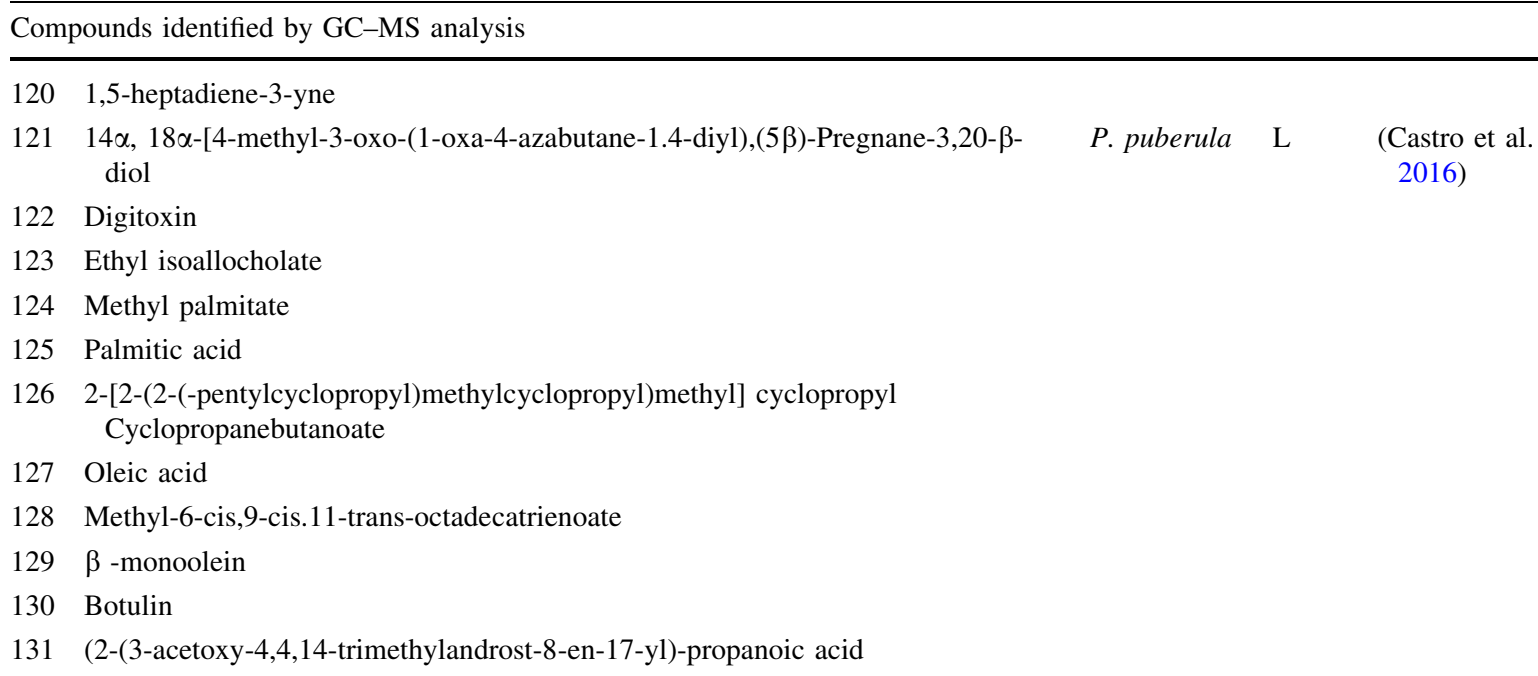

Plant parts used: $B$ bark; $F r$ : fruit; $F r-E-O$ fruit essential oil, $L$ leaves, $N S$ not specified, $R$ root, $S$ stem, $S B$ stem bark, $T w$ twig *Compound characterized by electrospray ionization Fourier transform ion cyclotron resonance mass spectrometry (ESI-FTICR-MS)

in the fruit essential oil of $P$. subcordata, nineteen compounds (102-120) in the leaf extract of $P$. dicoccos and eleven compounds (121-131) plus (1) in the hexane fraction of $P$. puberula leaf. One major drawback of characterizing compounds with GC-MS is the ability to match accurately the compounds in a mixture with exact spectra in GC-MS spectra database. GC-MS analysis of a complex mixture is not always $100 \%$ accurate; there is a huge possibility of assigning a wrong spectra to a wrong compound. Besides, GC-MS analysis is a destructive analytical method which could cause the breakdown of compounds and ultimately lead to identification of degradation products instead of the original constituents. Thus, in this review, we discovered that some of the compounds identified by GC-MS method are not natural products (for example, (111, 116 and 117)). For instance, (111) - a herbicide - might have accrued from the use of herbicides on the field where the plant material was harvested or it might be a product of a decomposed secondary metabolite. The expertise of the researcher in interpreting GC-MS spectra is also very important to avoid assigning wrong molecular formulae to compounds. One of the articles reviewed in this paper mistakenly gave a compound two synonymous names (furfural (102) and 2-Furancarboxaldehyde (107)) and assigned them two different molecular formulae. In summary, we will limit our phytochemistry review of the genus to isolated compounds whose structures were elucidated with other techniques (NMR, LC-MS andESI-FTICR-MS) apart from GC-MS.

Iridoids

Iridoids are a group of monoterpenoids recognized by their basic structure in which a pyran is fused to a cyclopentane, and are usually grouped into glycosidic, non-glycosidic, seco- and bis-iridoids (Ludwiczuk et al. 2017). Their activities could be likened to those of adaptogens and immunomodulators, and they are considered as prodrugs that get easily converted to active pyridine monoterpene alkaloids (Ghisalberti 1998). Chemical structures of iridoids are quite diverse and might be confusing if not well looked at because they often look alike. They play a role in ants' defence mechanism and are commonly found in plants infested with ants. Some patents have been filed for some natural iridoids in a recent review article for many biological activities (Hussain et al. 2019). However, many of them were in vitro investigation with most activities recorded at very high concentrations of iridoids which might be considered scientifically insignificant. For instance, in one of the patents 
recorded in Hussain et al. (2019) review article, an $\mathrm{IC}_{50}$ value of $104.1 \mu \mathrm{M}$ was presented for one of the phytoconstituents of Psydrax (21) as bioactive antiSARS agent. But all hope is not lost since iridoids are projected as pro-drugs whose activities could be greatly enhanced in vivo. It is worthy of note that some iridoids have shown good activities including cardiovascular, antihepatotoxic, hypoglycemic, hypolipidemic, anti-inflammatory, antispasmodic, antitumor, antiviral, and purgative activities (Ghisalberti 1998; Hussain et al. 2019; Tundis et al. 2008) at low concentrations. They are found naturally in varied forms in different plant species, and a good number has been documented for Pysdrax species. The structures of this class of compounds are captured in Fig. 1.

In a recent study, involving the stem bark of $P$. subcordata, two non-gylcosidic iridoids (1 and 2) were isolated, alongside other constituents (Awantu et al. 2019). Another set of non-glycosidic iridoids (3-8), which were novel and two known ones (9 and 10) were isolated from leaf and bark extracts of $P$. subcordata (Zhou et al. 2019). The largest number of iridoids (11-21) was isolated from iso-butanol fraction
Fig. 1 Iridoids and their glycosides
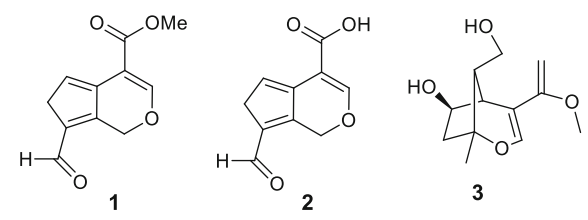

3

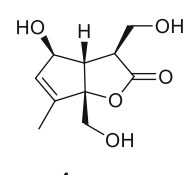

4
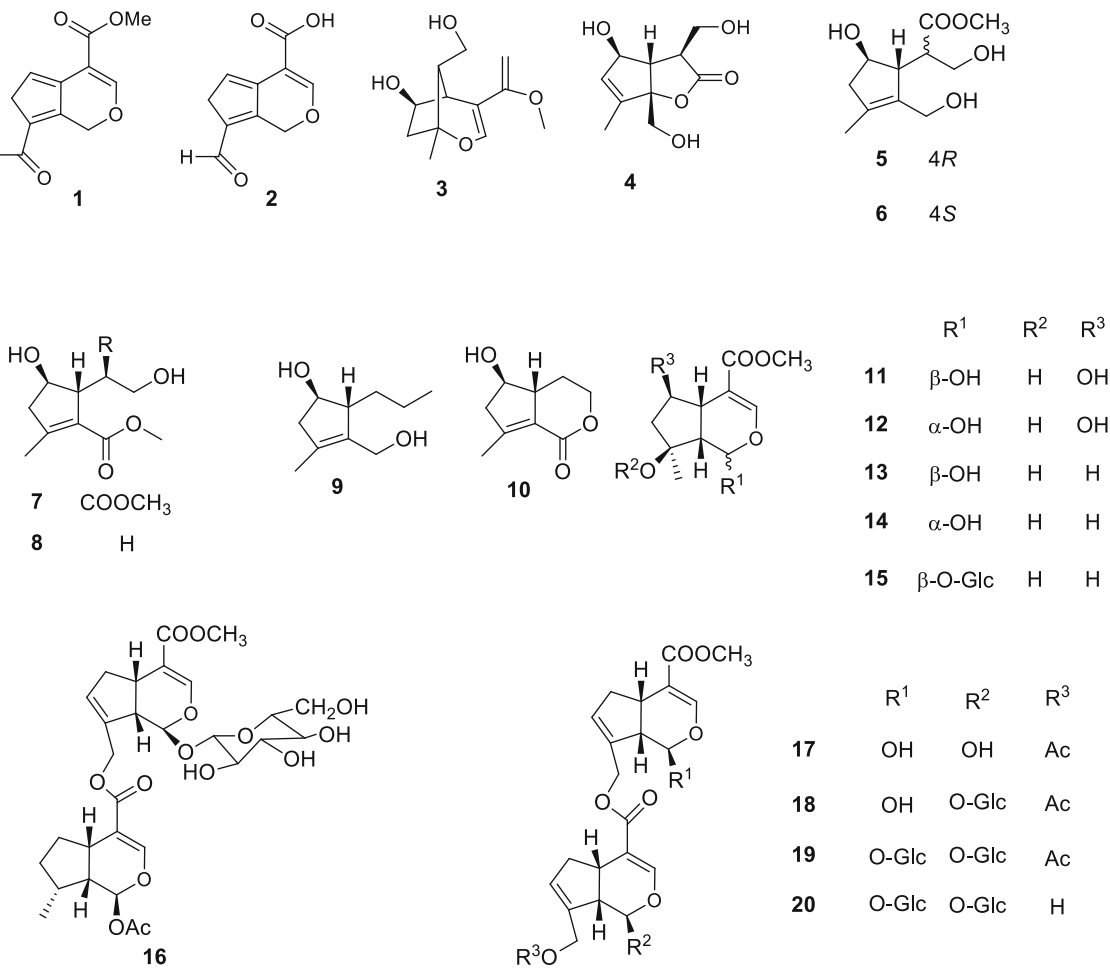

$\begin{array}{cccc} & \mathrm{R}^{1} & \mathrm{R}^{2} & \mathrm{R}^{3} \\ 17 & \text { OH } & \text { OH } & \text { Ac } \\ 18 & \text { OH } & \text { O-Glc } & \text { Ac } \\ 19 & \text { O-Glc } & \text { O-Glc } & \text { Ac } \\ 20 & \text { O-Glc } & \text { O-Glc } & \text { H }\end{array}$
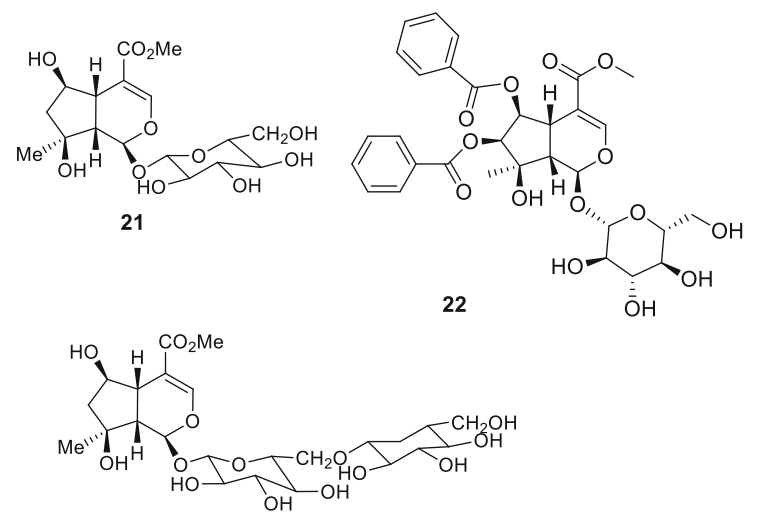

27

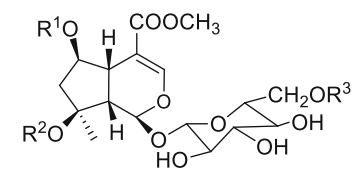

$\begin{array}{cccc} & \mathrm{R}^{1} & \mathrm{R}^{2} & \mathrm{R}^{3} \\ 23 & \mathrm{COC}_{6} \mathrm{H}_{5} & \mathrm{H} & \mathrm{H} \\ 24 & \mathrm{H} & \mathrm{COC}_{6} \mathrm{H}_{5} & \mathrm{H} \\ 25 & \mathrm{COC}_{6} \mathrm{H}_{5} & \mathrm{H} & \mathrm{Ac} \\ 26 & \operatorname{CoC}_{6} \mathrm{H}_{5} & \mathrm{H} & \mathrm{COC}_{6} \mathrm{H}_{5}\end{array}$ 
of methanol extract of $P$. subcordata dried fruits, and out of the eleven iridoids, five (16-20) were novel compounds (Joubouhi et al. 2015). Compound (22) was characterized in an extract of $P$. montigena using electrospray ionization Fourier transform ion cyclotron resonance mass spectrometry (ESI-FTICR-MS) (Yang et al. 2016), while (21 and 27) were obtained from the methanol extract of the stem bark of $P$. subcordata (Achenbach 1986; Achenbach et al. 1981), after an initial isolation of only (27) from the same extract (Achenbach et al. 1980). Out of the 22 iridoids so far isolated from $P$. subcordata, (21) is observed to be the most common and widely distributed iridoid of the species; it was isolated as the major component of the methanol extract of dry fruits and stem bark of $P$. subcordata. Another species that yielded iridoids is $P$. odorata; its leaf and bark produced four glycosidic iridoids (23-26), in company with other non-iridoid constituents (Coulerie and Poullain 2016; Sévenet and Pusset 1996). These data on iridoids suggest that the genus accumulates high amounts of this class of metabolites which may be of taxonomic relevance in plant systematics if further investigation is carried out.
Other terpenes and terpenoids

Terpenes are a class of compounds often found abundantly in essential oils because of their high volatility, and they are usually characterized using GC-MS technique. However, in this review, eight terpenes were isolated from three species of the genus and their structures and names are given in Fig. 2 and Table 4 respectively.

A non-glycosidic terpenoid (28) was isolated and characterized with NMR technique from the stem bark of the methanol extract of $P$. subcordata (Awantu et al. 2019) as well as in a GC-MS analysis of the n-hexane fraction of the leaves of $P$. puberula (Castro et al. 2016). The presence of (28) in two different species of the genus indicates possible similarities in the biosynthetic gene clusters of Psydrax species. In other studies, four non-glycosidic terpenoids (29-32) and three non-glycosidic terpenoids (33-35) were obtained from methanol extract of the stem bark and fruit of P. subcordata (Achenbach et al. 1981; Awantu et al. 2019; Joubouhi et al. 2015).
Fig. 2 Terpenes and their glycosides
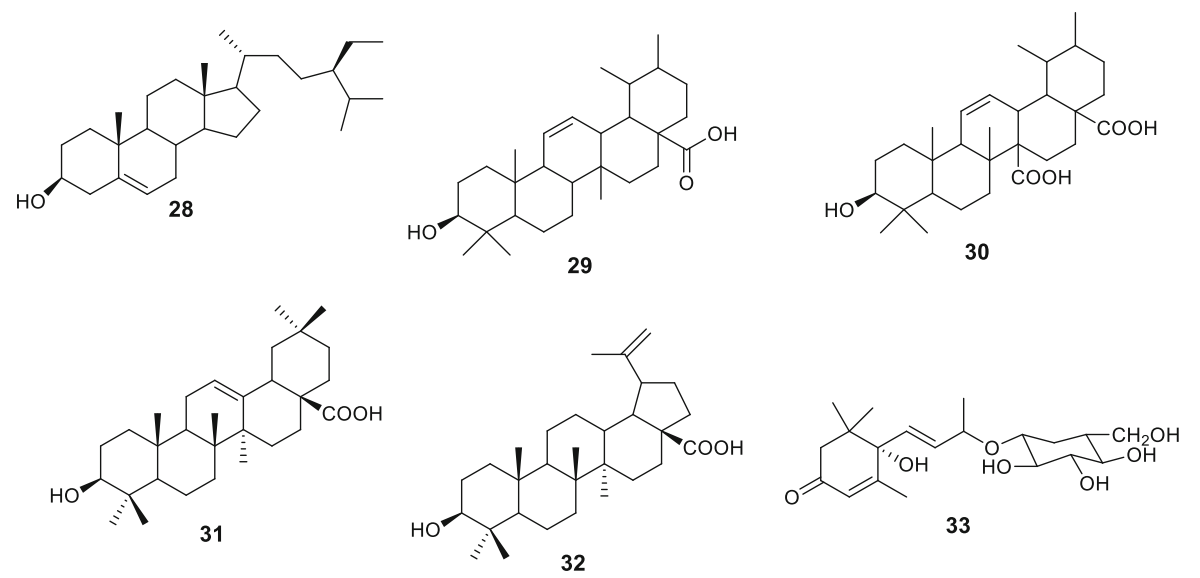

33

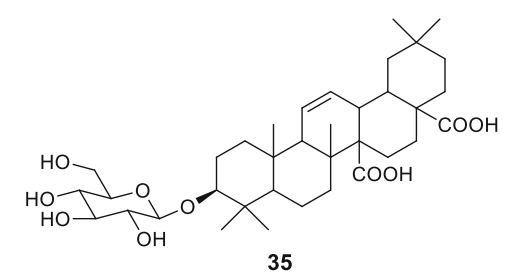


Cyanogenic glycosides

Cyanogenic glycosides are often considered toxic due to the ease of transformation of their aglycones to hydrogen cyanides a poisonous chemical (Yulvianti and Zidorn 2021), and could be seen as unimportant therapeutic agents. However, a bioactivity of this class of compound was reported by Tan et al (2012) in their study of the neuroprotective effects of prunasin gallates against $\mathrm{H}_{2} \mathrm{O}_{2}$ induced oxidative damage of NG108-15 cells. They reported in vitro neuroprotective property of highly glycosylated trigallates and tetragallate of prunasin (36), one of the compounds isolated from Psydrax, at a concentration of $100 \mu \mathrm{M}$ of the test samples and a positive control, catechin (Tan et al. 2012). It is obvious that this report was marred by the high concentration of test samples and the reference drug used. Also the bioavailability of these compounds are not guaranteed in vivo due to the high polarity of the glycosylated compounds and a possible loss of the sugar moiety in vivo. Apart from (36), two other cyanogenic glycosides (37 and 38) were isolated from methanol extracts of the leaf, stem and root of P. livida (Rockenbach et al. 1992) and the fourth cynogenic glycoside (40) was from a methanol extract of ripe fruits of $P$. schimperiana (Schwarz et al. 1996). The chemical structures of these compounds are shown in Fig. 3.

Fig. 3 Cyanogenic glycosides
Alkaloids

It is observed in the course of this review that alkaloid is not a common constituent of this genus and there are some conflicting claims as to whether they are present or absent in the genus. Some researchers discovered zero alkaloid when they chemically profiled the leaf, stem and root barks of $P$. subcordata, $P$. peruviana, and $P$. acutiflora (Denise P Ilboudo et al. 2013; Goh et al. 1997; Achenbach 1986; Achenbach et al. 1981; Daanaa et al. 2018; Akoto et al. 2019). On the contrary, some other research groups identified alkaloids in a different part of $P$. subcordata, $P$. horizontalis, $P$. schimperiana and $P$. dicoccos, but they reported the alkaloid content of $P$. schimperiana and $P$. dicoccos to be small (Anokwah et al. 2016; Feenna et al. 2020; Ochwang'i et al. 2016; Umaiyambigai et al. 2016). To confirm the presence of alkaloids in Psydrax, three alkaloids: two monoterpene alkaloids (40 and 41) and a peptide alkaloid (42) were isolated from $P$. odorata bark and leaf (Coulerie and Poullain 2016) and their structures are given in Fig. 4. The observed variations in alkaloid content of Psydrax species could be attributed to different factors, such as geographical differences, different harvesting seasons and analytical techniques and methods adopted by different authors and/or differences in the genetic make-up of different species of the genus. This inconsistency in the alkaloid contents of the genus calls for further extensive phytochemical studies of the genus across different geographical locations where<smiles>N#C[C@H](O[C@@H]1O[C@H](CO)[C@@H](O)[C@H](O)[C@H]1O)c1ccccc1</smiles>

36

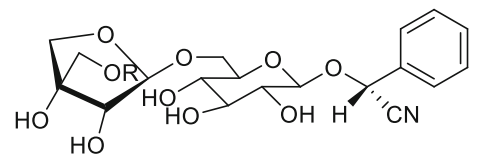

38
$\mathrm{R}$ $\mathrm{H}$ $\mathrm{C}_{6} \mathrm{H}_{5} \mathrm{CO}$

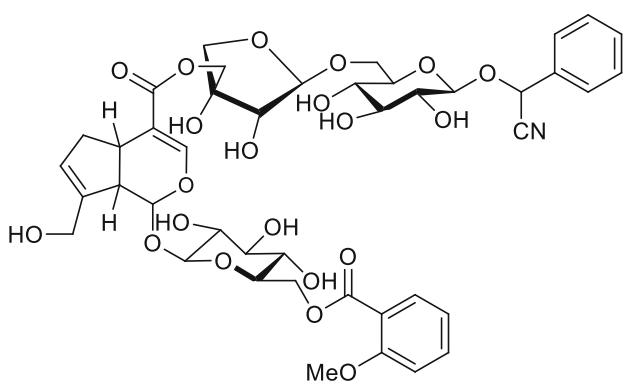


the species are endemic and adoption of a standard analytical technique and method that will provide a clearer perspective on the types of alkaloids and the alkaloidal content of the genus.

\section{Flavonoids}

Flavonoids are relatively rare in Psydrax, out of the 55 compounds isolated from the genus, only three were flavonoids: a flavone (43) isolated from the fruit of $P$. subcordata (Joubouhi et al. 2015, 2017), and a flavonol (44) and its glycoside (45) from $P$. dicoccos leaves (Gunasegaran et al. 2001). The structures of the flavonoids are given in Fig. 5.

Miscellaneous compounds

The remaining ten compounds are grouped under miscellaneous because of their less popularity in Psydrax and their structures are given in Fig. 6. They include, an aliphatic alcohol (46), an aromatic alcohol (47), a hydroxy coumarin (48), indole (49) which were obtained from the stem bark of $P$. subcordata (Achenbach 1986; Achenbach et al. 1981); chromone (50) obtained from the leaf and twig of $P$. acutiflora (Ilboudo et al. 2013); a cyclic glycoside (51) from stem bark of P. subcordata (Awantu et al. 2019); a glycosidic furanone (52) and aromatic ester (53) obtained from the leaf of P. livida (Nahrstedt et al. 1995); and two dicaffeoylquinic acids (54 and 55)

Fig. 4 Alkaloids

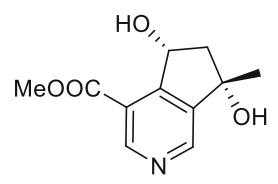

40

Fig. 5 Flavonoids and their glycosides isolated from the fruit of $P$. schimperiana (Schwarz et al. 1996).

\section{Pharmacological properties}

A few numbers of biological assays have been carried out on extracts and constituents of Psydrax species to support the acclaimed applications of these plants in the traditional management of a wide range of ailments. Unfortunately, only eight $(P$. subcordata, $P$. palma, $P$. acutiflora, $P$. montigena, $P$. schimperiana, $P$. livida, $P$. horizontalis and $P$. dicoccos) out of a hundred and thirty species of this genus, as well as $P$. peruviana which is not yet included in the WCSP database, have been pharmacologically tested for activities. Of the bioassays conducted for these species, majority are in vitro assays, three are in vivo studies and one is an ex vivo study. These conducted bioassays for the genus are summarized in Table 5 for record purposes, nothwithstanding the concentrations and methods used by different authors. However, only assays conducted with concentrations moderate enough to have any scientific importance are enumerated in the body of this text. It was observed by the current authors that for most in vitro assays conducted for this genus, only few of the studies performed cytotoxicity assay and determined selectivity index (SI) for their bioactive samples to verify the safety of the samples and predict their therapeutic margin. Among the species investigated for bioactivity, $P$.
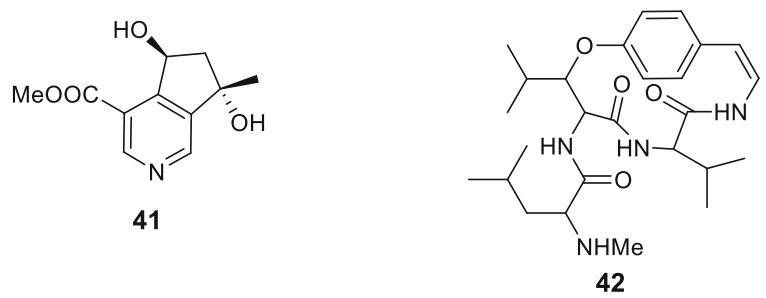<smiles>[R]Oc1cc(O)c2c(=O)c(O[C@@H]3O[C@H](CO[C@H]4O[C@H](C)[C@@H](O)[C@H](O)[C@H]4O)[C@@H](O)[C@H](O)[C@H]3O)c(-c3ccc(O)c(O)c3)oc2c1</smiles> 
Fig. 6 Miscellaneous Compounds
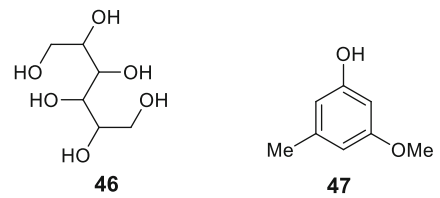<smiles>COc1cc2ccc(=O)oc2cc1O</smiles><smiles>c1ccc2[nH]ccc2c1</smiles><smiles>O=c1ccoc2ccccc12</smiles>

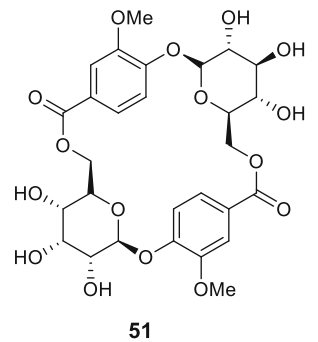<smiles>CC1=C(OOC(O)CCO)C(=O)C2OC1C2CO</smiles><smiles>O=C(/C=C/c1ccc(O)c(O)c1)OC1(O)COC2OCCOC(OC(=O)c3ccccc3)C(O)C(O)C1O2</smiles>

53<smiles>O=C(/C=C/c1ccc(O)c(O)c1)OC1CC(O)(C(=O)O)CC(OC(=O)/C=C/c2ccc(O)c(O)c2)C1O</smiles><smiles>O=C(/C=C/c1ccc(O)c(O)c1)OC1CC(O)(C(=O)O)CC(O)C1OC(=O)/C=C/c1ccc(O)c(O)c1</smiles>

55

subcordata is the most explored pharmacologically, while the leaf is the most investigated plant part. $P$. palma was referred to as Cathium oddonnii, its synonym, in two articles that reported its bioactivity.

Some of the compounds identified in Psydrax have previously been isolated from other medicinal plants and have shown varying pharmacological properties. For instance, $\beta$-sitosterol (28) was previously isolated from the stem bark of Solanum surattense and Pterospermum acerifolium, and these plants are used in the herbal treatment of a range of diseases including diabetes (Gupta et al. 2011; Muhit et al. 2010). In an attempt to support the traditional use of Solanum surattense in the herbal management of diabetes, Gupta et al. (2011) conducted a 21 day in vivo multiple dose $(10,15$ or $20 \mathrm{mg} / \mathrm{kg})$ antidiabetic assay of (28) as against $0.3 \mathrm{mg} / \mathrm{kg}$ of a reference drug, glibenclamide and also conducted acute toxicity assay of (28) in rats to determine the lethal dose (LD50: $120 \mathrm{mg} / \mathrm{kg}$ ) of the compound (28). They reported antidiabetic activity of (28) at all doses in comparison to the positive control $(0.3 \mathrm{mg} / \mathrm{kg})$, with $20 \mathrm{mg} / \mathrm{kg}$ having the best activity among the test doses. Though the activity of (28) was adjudged good, the comparison was done at a very high concentration $(20 \mathrm{mg} / \mathrm{kg})$ of the test compound as against glibenclamide $(0.3 \mathrm{mg} /$ $\mathrm{kg}$ ). In another in vivo multiple dose (15 and $30 \mathrm{mg} / \mathrm{kg}$ for 30 days) antidiabetic study of an ethyl acetate subfraction of an ethanol extract of the bark of Pterospermum acerifolium from which (28) was isolated, the authors reported good activity at $30 \mathrm{mg} / \mathrm{kg}$ of the fraction as against $0.6 \mathrm{mg} / \mathrm{kg}$ of STD drug used in the study (Rathinavelusamy et al. 2014). It was not clear to us what the STD drug was in the article. Rathinavelusamy et al. 2014 after isolating (28) from the most active fraction of Pterospermum acerifolium conducted an in silico antidiabetic study to determine the inhibitory activity of (28) against the human pancreatic $\alpha$-amylase (HPA). They revealed free binding energy and inhibition constant $\left(\mathrm{K}_{\mathrm{i}}\right)$ of -8.39 $\mathrm{kcal} / \mathrm{mol}$ and $0.269 \mu \mathrm{mol}$ for $(\mathbf{2 8})$, and $-6.07 \mathrm{kcal} / \mathrm{mol}$ and $28.52 \mu \mathrm{mol}$ for the reference drug, acarbose, and they presented (28) as a potential HPA inhibitor when compared to acarbrose (Rathinavelusamy et al. 2014). These reports are proof-of-concept of the potential antidiabetic property of (28) which is one of the phytoconstituents of the stem bark and leaf of a Psydrax species, P. subcordata (Awantu et al. 2019; Castro et al. 2016). 
Table 5 In vitro and in vivo assays of extracts and chemical constituents of Psydrax species

\begin{tabular}{|c|c|c|c|c|c|c|}
\hline Species & $\begin{array}{l}\text { Part of } \\
\text { plant } \\
\text { used }\end{array}$ & Extract & Compound & $\begin{array}{l}\text { Assay } \\
\text { method }\end{array}$ & Assay type & References \\
\hline \multirow[t]{4}{*}{ P. subcordata } & $\mathrm{R}$ & $\begin{array}{l}\mathrm{PE}, \mathrm{D}, \mathrm{E} \\
\mathrm{aM}\end{array}$ & - & In vitro & Antibacterial, anti-inflammatory & $\begin{array}{l}\text { (Awah et al. 2012; } \\
\text { Chukwujekwu et al. 2005) }\end{array}$ \\
\hline & SB & M & $\begin{array}{l}(1-10, \\
28-30,34 \\
35,51)\end{array}$ & In vitro & $\begin{array}{l}\text { Antiplasmodial, antibacterial, } \\
\text { antifungal, antioxidant, } \\
\text { antidiabetic }\end{array}$ & $\begin{array}{l}\text { (Anokwah et al. 2016; } \\
\text { Awantu et al. 2019; Zhou } \\
\text { et al. 2019) }\end{array}$ \\
\hline & $\mathrm{L}$ & $\mathrm{aE}$ & (3-10) & $\begin{array}{l}\text { In vivo } \\
\text { In vitro }\end{array}$ & Anticonvulsant Antidiabetic & $\begin{array}{l}\text { (Daanaa et al. 2018; Zhou } \\
\text { et al. 2019) }\end{array}$ \\
\hline & $\mathrm{Fr}$ & $\begin{array}{l}\text { E-O, EA, } \\
\text { iBu, M }\end{array}$ & $\begin{array}{l}(11,13, \\
15-19,21)\end{array}$ & In vitro & $\begin{array}{l}\text { Antioxidant, antibacterial, } \\
\text { antifungal, toxicity }\end{array}$ & $\begin{array}{l}\text { (Essien et al. 2015; Joubouhi } \\
\text { et al. 2017) }\end{array}$ \\
\hline P. palma & SB & M & - & In vitro & $\begin{array}{l}\text { Antiplasmodial, } \\
\text { antitrypanosomal }\end{array}$ & $\begin{array}{l}\text { (Memvanga et al. 2015; Mesia } \\
\text { et al. 2008) }\end{array}$ \\
\hline P. acutiflora & $\mathrm{L} / \mathrm{T}$ & $\begin{array}{l}\mathrm{H}, \mathrm{dP}, \mathrm{D} \\
\mathrm{EA}, \mathrm{aM} \\
\mathrm{W}\end{array}$ & - & In vitro & $\begin{array}{l}\text { Anti-inflammatory, } \\
\text { antiplasmodial }\end{array}$ & (Ilboudo et al. 2013) \\
\hline P. montigena & UsP & M & (22) & In vitro & Antiplasmodial & (Yang et al. 2016) \\
\hline \multirow{2}{*}{$\begin{array}{l}P . \\
\text { schimperiana }\end{array}$} & SB & D-M, W & - & In vitro & Cytotoxicity & (Ochwang'i et al. 2018) \\
\hline & $\mathrm{Fr}$ & M & $(39,51,52)$ & In vitro & Insecticidal & (Schwarz et al. 1996) \\
\hline P. livida & $\mathrm{L}$ & A & - & In vitro & Antibacterial & (Mukandiwa et al. 2012a) \\
\hline P. horizontalis & $\mathrm{L}$ & M & - & In vivo & antidiabetic & (Feenna et al. 2020) \\
\hline P. dicoccos & $\mathrm{L}$ & $\begin{array}{l}\text { PE, C, EA, } \\
\quad \text { M }\end{array}$ & - & In vitro & Antibacterial, antifungal & (Umaiyambigai et al. 2016) \\
\hline P. peruviana & SB & $\mathrm{H}, \mathrm{M}$ & - & In vitro & Antibacterial, antifungal & (Akoto et al. 2019) \\
\hline
\end{tabular}

Plant parts used: $F r$ fruit, $L$ leaves, $R$ root, $S B$ stem bark, $T$ twig, $N S$ not specified

Extracts used: $A$ acetone; $a E$ aqueous ethanol, $a M$ aqueous methanol, $C$ chloroform, $D$ dichloromethane, $D$ - $M$ dichloromethanemethanol mixture, $d P$ di-iso-propyl, $E-O$ essential oil, $E$ ethanol, $E A$ ethyl acetate, $H$ hexane, $i B u$ iso-butanol, $M$ methanol, $P E$ petroleum ether, $W$ water

\section{Antimicrobial activity}

European Committee on Antimicrobial Susceptibility Testing (EUCAST), and Clininal and Laboratory Standards Institute (CLSI) provide standard methods called antimicrobial susceptibility testing (AST) for conventional antimicrobials for rational comparison among antimicrobial assay results generated by researchers (Bubonja-Šonje et al. 2020). Unfortunately, there are no such established methods for assessing the antimicrobial properties of plant materials due to the complexity of plant samples and this leads many researchers to adopting varied modified AST to achieve their desired goals (Bubonja-Šonje et al. 2020). The result of these of these incoherent test methods is the generation of incomparable, difficultto-interpret and often times misinterpreted research outcomes (Bubonja-Šonje et al. 2020; Cos et al. 2006; Eloff 2019; Gertsch 2009). This is what was observed in the course of this review, different researchers adopted varying test methods; different concentrations of plant samples were used; test organisms and media were not similar in many cases; and endpoint parameters (MIC, $\left.\mathrm{IC}_{50}\right)$ assessed were dissimilar (Cos et al. 2006).

Some of the articles reviewed reported sample concentrations far above the recommended MIC value for plant extracts and pure compounds $((0.1 \mathrm{mg} / \mathrm{mL}$ $(100 \mu \mathrm{g} / \mathrm{mL})$ for extracts/fractions or less than $25 \mu \mathrm{M}$ for pure compounds), and acceptable maximum in-test concentration of $1 \mathrm{mg} / \mathrm{mL}$ for plant mixtures and $0.1 \mathrm{mg} / \mathrm{mL}$ for pure plant constituents (Ríos and Recio 2005); many articles reported activity as minimum inhibitory concentration (MIC) values instead of 
concentration at $50 \%$ inhibition $\left(\mathrm{IC}_{50}\right)$, which is adjudged to be scientifically significant at a value less than $0.1 \mathrm{mg} / \mathrm{mL}(100 \mu \mathrm{g} / \mathrm{mL})$ for extracts/fractions or less than $25 \mu \mathrm{M}$ for pure compounds; some authors used concentration of microbial inoculum greater than the acceptable standard of $10^{5} \mathrm{CFU} / \mathrm{mL}$ for bacteria and $10^{3}$ or $10^{4} \mathrm{CFU} / \mathrm{mL}$ for fungi (Cos et al. 2006). Another crucial observation made in this review is that, some authors adopted agar diffusion method which is not a generally acceptable standard method for determining the MICs of plant extracts/fractions because of the low polarity of most plant's antimicrobial constituents which often hinders their diffusion through the polar agar medium used for the tests and ultimately leads to false negative result (Eloff 2019). Eloff also pointed out that an MIC value less than $0.1 \mathrm{mg} / \mathrm{mL}$ is scientifically relevant for further antimicrobial studies, that anything above this benchmark should not be pursued for further investigation (Eloff 2019). Being guided by these recommendations, we hereby enumerate only the in vitro antimicrobial assay results of extracts and pure compounds of the genus whose $\mathrm{IC}_{50} / \mathrm{MIC}$ value is less than $100 \mu \mathrm{g} / \mathrm{mL}$ for plant extract/fraction and less than $25 \mu \mathrm{M}$ or $<10 \mu \mathrm{g} /$ $\mathrm{mL}$ for pure compounds, as well as those that used microbial inoculum concentration of $10^{5} \mathrm{CFU} / \mathrm{mL}$ for bacteria and $10^{3}$ or $10^{4} \mathrm{CFU} / \mathrm{mL}$ for fungi. To the best of our knowledge, no antimicrobial in vivo assay nor clinical trial has been reported for either the extracts nor phytoconstituents of this genus.

Antimicrobial assay conducted by Awantu et al. (2019) for eight compounds $(\mathbf{1}, \mathbf{2}, \mathbf{2 8}, \mathbf{2 9}, \mathbf{3 0}, \mathbf{3 4}, 35$ and 51) they isolated from the stem bark of $P$. subcordata, against three Gram positive bacteria (Staphylococcus aureus, Staphylococcus saprophiticus, Streptococcus faecalis), three Gram negative bacteria (Klebsiella pneumonia, Pseudomonas aeruginosa) and two fungi species (Candida albicans and Candida krusei) using broth dilution method showed only (1, 2 and 30) to be effective. They reported the following results for the three active compounds using gentamicin ( $\mathrm{IC}_{50} 2.4 \mu \mathrm{g} / \mathrm{mL}$ ) and nystatin ( $\mathrm{IC}_{50}$ $4.8 \mu \mathrm{g} / \mathrm{mL}$ ) as positive control for bacteria and fungi, respectively: (1) was active against only $C$. albicans ( $\left.\mathrm{IC}_{50} 9.7 \mu \mathrm{g} / \mathrm{mL}\right) ;(2)$ was active against $C$. albicans ( $\mathrm{IC}_{50} 4.8 \mu \mathrm{g} / \mathrm{mL}$ ), C. krusei ( $\mathrm{IC}_{50} 9.7 \mu \mathrm{g} / \mathrm{mL}$ ) and $S$. aureus $\left(\mathrm{IC}_{50} 9.7 \mu \mathrm{g} / \mathrm{mL}\right)$; (30) was active against $C$. albicans $\left(\mathrm{IC}_{50} 9.7 \mu \mathrm{g} / \mathrm{mL}\right), K$. pneumonia $\left(\mathrm{IC}_{50}\right.$ $9.7 \mu \mathrm{g} / \mathrm{mL}$ ) and $P$. aeruginosa ( $\mathrm{IC}_{50} 4.8 \mu \mathrm{g} / \mathrm{mL}$ )
(Awantu et al. 2019). In another study conducted by Joubouhi et al. (2017) for the fourteen compounds (11, $12,13,14,15,16,17,18,19,20,21,31,32$ and 43) they isolated from the fruit extract of $P$. subcordata using micro dilution method, only (13) displayed antibacterial activity against a Gram-positive bacterium, $S$. aureus, with an MIC value of $8 \mu \mathrm{g} / \mathrm{mL}$; they used two reference drugs - ampicillin (MIC $8 \mu \mathrm{g} / \mathrm{mL}$ ) and ciprofloxacin (MIC $2 \mu \mathrm{g} / \mathrm{mL}$ ). None of the compounds was active against any of the Gramnegative bacteria strains (four strains of Vibrio cholerae, and Shigella flexneri) used by the authors (Joubouhi et al. 2017).

In a preliminary study to support the use of $P$. livida leaves in the traditional treatment of wound myiasis in animals, a group of researchers Mukandiwa et al. (2012b) carried out an in vitro antibacterial assay of four extracts (hexane, dichloromethane, acetone and methanol) of $P$. livida leaves against two Grampositive bacteria (Staphylococcus aureus and Enterococcus faecalis) and two Gram-negative bacteria (Pseudomonas aeruginosa and Escherichia coli), which are implicated in the pathogenesis of wound myiasis, by adopting microdilution assay method. They discovered that the dichloromethane extract was the most active among the extracts. However, the dichloromethane extract was active against only $S$. aurus with MIC values of $78 \mu \mathrm{g} / \mathrm{mL}$ as against the MIC value $(0.78 \mu \mathrm{g} / \mathrm{mL})$ for gentamycin, the reference drug.

Antimicrobial assay conducted by Castro et al. (2016) for crude extract and three fractions (hexane, chloroform and butanol) of $P$. puberula leaf against $S$. aureus, $P$. aeruginosa and E. coli, using microdilution method, showed varying antimicrobial activity. The crude extract and three fractions were all active against only $S$. aureus with MIC values ranging from $31.25-62 \mu \mathrm{g} / \mathrm{mL}$ as against the MIC value of about $3.91 \mu \mathrm{g} / \mathrm{mL}$ of ciprofloxacin, the positive control (Castro et al. 2016). An antifungal assay of $P$. subcordata mature fruits' essential oil against $A$. niger showed activity with an MIC value of $39 \mu \mathrm{g} / \mathrm{mL}$ in comparison to a positive control, amphotericin B (MIC value of $0.61 \mu \mathrm{g} / \mathrm{mL}$ ) (Essien et al. 2015); the essesntial oil showed no significant activity against any of the bacteria species (Bacillus cereus, S. aureus, E. coli and P. aeruginosa) tested. From these enumerated antimicrobial properties, Psydrax could hold a promise in the discovery of antibacterial and 
antifungal agents with broad spectrum of activity. However, more research works, especially in vivo study of the active samples and cytotoxic assays, is needed to substantiate this knowledge-informed hypothesis. These few promising antimicrobial properties observed for the extracts and constituents of the genus support some of its traditional applications in the treatment of diarrhoea and wound myiasis.

\section{Anti-inflammatory activity}

It is recommended that every biological assay should be conducted by adopting a standardized procedure for the assay, using as small an amount of plant sample as possible and a standard positive control (Cos et al. 2006). Whenever a too low or too high concentration is used, a false negative or positive result will prevail. For anti-inflammatory assays, Chukwujekwu et al. (2005) rightly observed that recording a relatively good in vitro prostaglandin synthesis inhibition for a non-polar extract as against more polar extracts does not corroborate the traditional use of the aqueous extracts in the traditional management of inflammation (Chukwujekwu et al. 2005). The possibility of aqueous herbal extracts to elicit anti-inflammatory effect in folkloric medicine could be linked to the high phenolic content of aqueous extracts which are mainly antioxidants and could give anti-inflammatory effect by improving the immune system of the patient (Eloff 2019). For the Psydrax genus, different in vitro and in vivo anti-inflammatory assays have been carried out for different extracts of $P$. subcordata and $P$. acutiflora, but we will only report results that used maximum in-test concentration of $1 \mathrm{mg} / \mathrm{mL}$ of plant extracts/fractions or $0.1 \mathrm{mg} / \mathrm{mL}$ of pure plant constituents in in vitro assays, and in vivo oral concentration of not more than $100 \mathrm{mg} / \mathrm{kg}$ for extracts.

Unfortunately, only the in vivo study done by Anokwah et al.( 2016) fell within our chosen concentration range. In an in vivo per oral (p.o.) antiinflammatory assay they conducted for the methanol stem bark extract of $P$. subcordata using carrageenaninduced footpad oedema in seven-day-old chicks, the authors reported dose-dependent percentage oedema inhibitions of $61.21,53.00$ and $49.34 \%$ at 300,100 and $30 \mathrm{mg} / \mathrm{kg}$ body weight p.o. doses, respectively, of the extract using two positive controls, dexamethasone $(0.3,1$ and $3.0 \mathrm{mg} / \mathrm{kg})$ and diclofenac $(10,30$, and $100 \mathrm{mg} / \mathrm{kg}$ ) given intraperitoneally (Anokwah et al.
2016). Though they recorded anti-inflammatory activity for the plant extract, the concentrations used for the extract were higher than those of the positive control coupled with different routes of administration used for the test sample and the controls.

Antiparasitic activity

Antiparasitic assay like other anti-infection assays should follow some recommended standards previously mentioned to guarantee the authenticity of its results. Psydrax species have found applications in traditional management of malaria and fever, and in attempts to support this ethnomedicinal claim, some researchers conducted in vitro antiplasmodial assay of different extracts and constituents of the genus and they came up with varied antiplasmodial activities for the genus. However, it was observed that majority of these in vitro studies investigated either susceptible or resistant strains of Plasmodium falciparium and not both strains as deemed appropriate for a primary in vitro antiplasmodial assay (Cos et al. 2006). For studies that determined the $\mathrm{IC}_{50}$ of test samples (extracts), the $\mathrm{IC}_{50}$ values they obtained were within the acceptable range of below $100 \mu \mathrm{g} / \mathrm{mL}$ for crude extracts, but toxicity assays were not conducted for these active extracts to confirm that the activities reported were not due to non-specific activity and potential toxicity of the extracts (Cos et al. 2006).

In a study involving stem bark methanol extract of $P$. subcordata against a chloroquine resistant $P$. falciparum $\mathrm{W} 2$, there was an inhibition against the parasite with an $\mathrm{IC}_{50}$ of $3.044 \mu \mathrm{g} / \mathrm{mL}$, however, fractions and constituents $(1,2,28,29,30,34,35$ and 51) from the extract showed no activity against the parasite strain (Awantu et al. 2019). However, the authors did not give the $\mathrm{IC}_{50}$ value for the positive control. In another study, $80 \%$ methanol extract of $P$. palma, showed parasitic inhibition against a chloroquine-sensitive P. falciparum strain (positive control: chloroquine $2 \mathrm{H}_{3} \mathrm{PO}_{4}-\mathrm{IC}_{50} 0.08 \mu \mathrm{g} / \mathrm{mL}$ ), Trypanosoma brucei brucei (positive control: suramin $\mathrm{IC}_{50} 0.08 \mu \mathrm{g} / \mathrm{mL}$ ), and Trypanosoma cruzi (positive control: suramin - $\mathrm{IC}_{50} 0.05 \mu \mathrm{g} / \mathrm{mL}$ ), with the same $\mathrm{IC}_{50}>64 \mu \mathrm{g} / \mathrm{mL}$, using 96-well tissue culture plates method (Mesia et al. 2008). They also conducted cytotoxicity test for the extract against the MRC-5 human cell-line and got the same $\mathrm{IC}_{50}$ value, but they reported the extract as inactive at this $\mathrm{IC}_{50}$ comparing 
its activity with the activities of extracts from other plants having $\mathrm{IC}_{50}$ as low as $0.7 \mu \mathrm{g} / \mathrm{mL}$ and did not calculate the selectivity index (SI) for the extract.

In another study involving different extracts (hexane, diisopropyl ether, dichloromethane, ethyl acetate, and methanol-water) of $P$. acutiflora leaf/twig, tested against chloroquine susceptible and resistant strains of $P$. falciparum, using the parasite lactate dehydrogenase assay method, the exracts displayed variable $\mathrm{IC}_{50}$ values against the two strains of the parasite. The diisopropyl ether extract showed highest activity against the parasite strain $\left(\mathrm{IC}_{50} 8.8 \mu \mathrm{g} / \mathrm{mL}\right.$ and $\mathrm{IC}_{50}$ $9.5 \mu \mathrm{g} / \mathrm{mL}$ ) against the susceptible and resistant strains respectively, while the ethyl acetate extract was the least active $\left(\mathrm{IC}_{50} 61.3 \mu \mathrm{g} / \mathrm{mL}\right)$ against the sensitive strain and methanol-water extract showed least activity $\left(\mathrm{IC}_{50} 64.8 \mu \mathrm{g} / \mathrm{mL}\right.$ ) against the resistant strain. Chloroquine used as the positive control for this study had an $\mathrm{IC}_{50}$ of $0.20 \mu \mathrm{g} / \mathrm{mL}$ and $\mathrm{IC}_{50} 0.009 \mu \mathrm{g} /$ $\mathrm{mL}$ against the sensitive and resistant strains respectively (Ilboudo et al. 2013). (Ilboudo et al. 2013) also tested the in vitro antiplasmodial activity of the most abundant constituent (50) of the diisopropyl extract and reported less activity ( $\mathrm{IC}_{50} 18.1 \mu \mathrm{g} / \mathrm{mL}$ and $\mathrm{IC}_{50}$ $43.4 \mu \mathrm{g} / \mathrm{mL}$ ) for (50) against the sensitive and resistant strains, respectively, in comparison with the diisopropyl extract. In addition to these antiplasmodial tests, (Ilboudo et al. 2013) also conducted cytotoxicity tests and calculated SI for the aqueous extract of $P$. acutiflora with $\mathrm{IC}_{50} 80.0$ and $46.91 \mu \mathrm{g} / \mathrm{mL}$ against the sensitive and resistant strains of organism, respectively, and obtained a $\mathrm{CC}_{50}$ value of $615.4 \mu \mathrm{g} / \mathrm{mL}$ and SI values of 7.7 and 13.1 for the sensitive and resistant strains, respectively.

\section{Anticonvulsant activity}

In the quest to support the folkloric use of ethanol extract of $P$. subcordata in the management of epileptic seizures, Daanaa and co-workers used varying animal models in in vivo anticonvulsant assays of $70 \%$ ethanol extract of the leaves of P. subcordata. They explored the following animal models and reference drugs: pentylenetetrazole-induced seizure (reference drug: diazepam $(0.3,1$ or $3 \mathrm{mg} / \mathrm{kg}$, i.p.)); picrotoxin-induced seizure (reference drug: diazepam $(0.3,1$ or $3 \mathrm{mg} / \mathrm{kg}$, i.p.)); maximal electroshock (reference drug: carbamazepine $(3,10$ or $30 \mathrm{mg} / \mathrm{kg}$, p.o)); strychnine-induced seizure (reference drug: diazepam (1 mg/kg, i.p.)); 4-aminopyridine-induced seizure (reference drug: sodium valproate, $(100,300$ or $600 \mathrm{mg} / \mathrm{kg}$, p.o.)); and lithium/pilocarpine-induced status epilepticus (reference drug: diazepam $(1 \mathrm{mg} / \mathrm{kg}$, i.p.), and discovered that the extract worked by delaying the onset of seizure and reducing the duration and frequency of induced convulsions in most of the animal models, at study doses of 30, 100 and $300 \mathrm{mg} /$ $\mathrm{kg}$ (p.o.). However, in electroshock and strychnineinduced test models, the hydroethanol extract failed to delay the onset of tonic hind limb extensions and the onset of seizure, respectively (Daanaa et al. 2018). Though the doses of the extract used in this study were ten times those of the reference drugs, this report by Daanaa et al. gives a pharmacological insight to the use of ethanol extract of $P$. subcordata leaves in the ethnomedicinal management of epileptic convulsion and presents the plant as a possible source of anticonvulsant agents if further investigated to find out if there could be any synergistic effect of using the extract in a combination therapy, since herbal medicines are often administered as a mixture of many extracts. Another way to ascertain the use of this extract in traditional medicine is by screening and isolating the active constituent(s) of the extract and carrying out extensive assays (in vitro and in vivo) on the isolated compound(s) and ultimately conduct clinical studies to substantiate their activities. This study by Daanaa et al. (2018) is the only anticonvulsant assay so far done for this genus.

Antihyperglycemic/antidiabetic activity

In a bid to support or refute the ethnomedicinal use of $P$. subcordata bark in the management of diabetes, Zhou et al. (2019) carried out an in vitro protein tyrosine phosphatase 1B (PTP1B) inhibitory assay on eight iridoids (3-10) isolated from ethanol extracts of $P$. subcordata leaves and bark. Only (3), one of the six novel iridoids (3-10) showed relavant enzyme inhibition with an $\mathrm{IC}_{50}$ value of $22.2 \mu \mathrm{M}$ in comparison with the positive control, oleanolic acid ( $\mathrm{IC}_{50} 4.3 \mu \mathrm{M}$ ). Though this is not very fantastic, but chemical modification of the compound could lead to a better activity. To prove this assertion, when the structures of two enantiomers, subcordatanol III (5) and subcordatanol IV (6) were transformed to subcordatalactons $\mathrm{A}$ and $\mathrm{B}$, respectively, their antihyperglycemic property dramatically improved from $\mathrm{IC}_{50}$ value of $>80$ 
$\mu \mathrm{M}$ to 8.9 and $9.8 \mu \mathrm{M}$ for $\mathrm{A}$ and $\mathrm{B}$, respectively (Zhou et al. 2019). We recommend in vitro cytotoxicity assay and calculation of SI for (3) as well as in vivo assays to determine its bioavailability and mechanism of action.

Antioxidant activity

Since the antioxidant activity recorded for this genus was from in vitro assay, which is not a sufficient prove of a possible in vivo efficacy of the samples as antioxidants, we hereby present the in vitro radical scavenging results as an indication of the phytoconstituents of the species rather than as a bioactivity. Many a time, extracts that exhibit in vivo antioxidant property are usually high in phenolic content, But, the phytochemical analysis of the eight studied species of Psydrax gave only three flavonoids as phenolic compounds which might be considered too small to accord the genus antioxidant properties. Surprisingly, some of the extracts and isolated compounds of the genus exhibited in vitro radical scavenging properties. We decided to present in vitro radical scavenging results of extracts with $\mathrm{IC}_{50}$ or $\mathrm{EC}_{50}$ values less than 10 or $100 \mu \mathrm{g} / \mathrm{mL}$ for compounds or extracts/fractions and to exclude results with very high concentrations of no scientific relevance. In a study conducted by Awah et al. (2012), 80\% methanol root extract of $P$. subcordata displayed DPPH radical scavenging property with an $\mathrm{EC}_{50}$ value of $23.9 \mu \mathrm{g} / \mathrm{mL}$ in comparison to ascorbic acid of $\mathrm{EC}_{50}$ value of $4.9 \mu \mathrm{g} / \mathrm{mL}$. Akoto et al. (2019) reported that the methanol extract of $P$. peruviana stem bark also displayed DPPH radical and hydrogen peroxide scavenging activities with $\mathrm{IC}_{50}$ values of 12.20 and $24.26 \mu \mathrm{g} / \mathrm{ml}$, respectively. Two iridoids (13 and 17) isolated from the fruit extracts of $P$. subcordata reportedly displayed DPPH radical scavenging activity with $\mathrm{EC}_{50}$ values of $1.12 \mu \mathrm{g} / \mathrm{mL}$ and $2.03 \mu \mathrm{g} / \mathrm{mL}$ for (13) and (17), respectively in comparison with $\mathrm{EC}_{50}$ of $1.74 \mu \mathrm{g} / \mathrm{mL}$ for vitamin $\mathrm{C}$, the positive control (Joubouhi et al. 2017). (13) and (17) are not polyphenolic compounds with inherent antioxidant properties, neither are they glycosidic, yet they exhibited radical scavenging properties. Thus, their radical scavenging properties needs further investigation - probably in vivo studies - to confirm the activity and elucidate the mechanism of action of these extracts and compounds.
Toxicity

Toxicity assays are very paramount in discovering new drugs to confirm the safety of any bioactive extract/fraction or compound. It is also a test of activity of a sample against malignant cells. As previously pointed out, only few researchers take the time to carry out in vitro cytotoxicity assay to test the safety of their plant samples. It is observed in the course of this review that most of the in vitro toxicity tests were done without determining the selectivity index of test samples; an important parameter needed to establish the safety of a sample to healthy cells. Daanaa et al. 2018, in their anticonvulsant in vivo assay of the aqueous ethanol extract $P$. subcordata also determined the acute toxicity of the extract in animal model and reported no death in 14 days the test lasted, but observed reduced activity and sedation of the animals at doses between 300 and $3000 \mathrm{mg} / \mathrm{kg}$ body weight. In a different study, extracts and isolated constituents (62-74) of $P$. subcordata fruits showed no hemolysis against human red blood cells at maximum concentrations of 512 and $256 \mu \mathrm{g} / \mathrm{mL}$ respectively, and are adjudged to be safe to normal cells (Joubouhi et al. 2017). Feenna and co-researchers reported that acute toxicity and lethality assays of methanol leaf extract of $P$. horizontalis in rats, showed no mortality at the maximum lethal dose of $5000 \mathrm{mg} / \mathrm{kg}$ of extract (Feenna et al. 2020). However, contrary to the forgoing non-toxic reports about the genus extracts, in a study involving $80 \%$ methanol extract of the root of $P$. subcordata, there was toxicity against human peripheral blood mononuclear cells (PBMC), even at extract's concentration of as low as $10 \mu \mathrm{g} / \mathrm{mL}$ compared to a negative control (Awah et al. 2012). No relevant bioactive cytotoxicity of the extracts, fractions or compounds of this genus was encountered by authors in the course of this review. We therefore recommend that more toxicity assays be conducted for extracts and constituents of Psydrax species to ascertain their efficacy against abnormal cells and safety to normal cells.

\section{Conclusion}

We are projecting in this review that the chemotaxonomic marker for Psydrax is iridoid. This projection is evidenced in the number of iridoids (twenty-seven) 
isolated out of the fifty-five isolated components of the genus. The current review reveals that investigations so far carried out on Psydrax are mainly in vitro studies, with very few in vivo studies. No in silico study has been done on the isolated constituents of Psydrax, nor any clinical trial so far. The limited in vivo studies of this genus could be one of the reasons why little scientifically significant activities have been recorded for the genus considering the fact that the major constituent of the genus is iridoid, and iridoids are seen as pro-drugs which need to be biotransformed in vivo to elicit activities. Thus, in vivo assays of these plants are strongly recommended by the authors to reveal the hidden treasure of the genus. Many of the documented studies lack depth and thus require further investigation for an evidencebased application of medicinally active species within the genus. Although some documented bioactive phytochemicals reported in a few species of Psydrax correlate well with the traditional uses of the plants, many of the studies are more or less preliminary with results of some being low to be given any further scientific attention. Future research study is strongly recommended to be focused on the characterization of bioactive constituents of plant species in the genus and subsequent in vitro and in vivo studies, adopting standard bioassay and analytical methods to ensure consistent and generally acceptable results that could be pursued for potential drug leads. It is also evidenced from this review that the genus is a good source of novel compounds with varying bioactivities, which might qualify as potential leads in drug discovery. Unfortunately, only about six percent of Psydrax species have been explored for their ethnobotanical uses, phytochemicals and pharmacological properties; and this represents a lacuna that needs to be filled. There is therefore, a scientific need for further exploration of the genus in order to discover its several other ethnomedicinal applications, phytochemicals and pharmacological properties. In conclusion, authors recommend authentic in vitro, in silico, in vivo assays and even clinical trials of extracts and phytoconstituents of this genus, adopting standard assay methods. They also suggest sustainable utilization of plant resources under this genus via useinformed cultivation and domestication of medicinally important species in order to forestall the loss of species and the decline in plant biodiversity particularly in Africa where many of the species under this genus are endemic.

Authors' contributions AFA Conception and design of the work and critical revision of the manuscript. UMC Data collection, data analysis and drafting of the manuscript. FBCO Critical revision of the manuscript and final approval of the version to be published.

Funding The study has not received any kind of funding.

Data availability Not applicable.

Code availability Not applicable.

\section{Declarations}

Conflict of interest There was no conflict of interest among the authors.

Ethical approval Not applicable.

Consent to participate Not applicable.

Consent for publication Not applicable.

\section{References}

Achenbach H (1986) Investigations on West African medicinal plants. Pure Appl Chem 58(5):653-662. https://doi.org/10. 1351/pac198658050653

Achenbach H, Waibel R, Addae-Mensah I (1980) Shanzhisin methyl ester gentiobioside, a New Iridoid - isolation and synthesis. Tetrahedron Lett 21(38):3677-3678. https://doi. org/10.1016/S0040-4039(00)78742-9

Achenbach H, Waibel R, Raffelsberger B, Addae-Mensah I (1981) Iridoid and other constituents of canthium subcordatum. Phytochemistry 20(7):1591-1595. https://doi.org/ 10.1016/S0031-9422(00)98538-8

Agyare C, Asase A, Lechtenberg M, Niehues M, Deters A, Hensel A (2009) An ethnopharmacological survey and in vitro confirmation of ethnopharmacological use of medicinal plants used for wound healing in bosomtwiatwima-kwanwoma area, ghana. J Ethnopharmacol 125(3):393-403. https://doi.org/10.1016/j.jep.2009.07.024

Akoto CO, Acheampong A, Boakye YD, Takyi S, Garba R (2019) Phytochemical screening and in vitro antioxidant and antimicrobial activities of the extracts of the stem-bark of psydrax peruviana. Journal of Medicinal Plants Studies 7(5):28-34

Anokwah D, Mensah AY, Amponsah IK, Mireku EA, Mintah DN (2016) Anti-inflammatory, antioxidant and antimicrobial activities of the stem bark of psydrax subcordata. Pharm Lett 8(20):21-28

Appiah K, Oppong C, Mardani H, Omari R, Kpabitey S, Amoatey C, Onwona-Agyeman S, Oikawa Y, Katsura K, 
Fujii Y (2018) Medicinal plants used in the ejisu-juaben municipality, southern ghana: an ethnobotanical study. Medicines 6(1):1-27. https://doi.org/10.3390/ medicines6010001

Arriola AH, Alejandro GJD (2013) A new species of psydrax (Vanguerieae, Rubiaceae) from Luzon, Philippines including its conservation status. Phytotaxa 149(1):27-30. https://doi.org/10.11646/phytotaxa.149.1.4

Arriola AH, Cobangkiat AB, Alejandro GJD (2017) Psydrax Multiflora Sp. Nov. (Rubiaceae) from Palawan, Philippines. Nord J Bot 35(2):182-184. https://doi.org/10.1111/ njb.01255

Asfaw A, Lulekal E, Bekele T, Debella A, Abebe A, Degu S (2021) Ethnobotanical investigation on medicinal plants traditionally used against human ailments in ensaro district, north shewa zone, amhara regional state, ethiopia. Research Square. https://doi.org/10.21203/rs.3.rs-720404/ v1

Awah FM, Uzoegwu PN, Ifeonu P, Oyugi JO, Rutherford J, Yao X, Fehrmann F, Fowke KR, Eze MO (2012) Free radical scavenging activity, phenolic contents and cytotoxicity of selected nigerian medicinal plants. Food Chem 131(4):1279-1286. https://doi.org/10.1016/j.foodchem. 2011.09.118

Awantu AFFAF, Fotsing FYS, Bankeu KJJ, Lenta NB, Tsouh FPVPV, Boyom FFFFF, Assob NJCJC, Tsamo E, Sewald N (2019) Antiplasmodial and antimicrobial potential of canthium subcordatum extracts and isolates. J Phytopharmacol 8(2):52-56. https://doi.org/10.31254/phyto.2019. 8205

Bremer B (2009) A review of molecular phylogenetic studies of rubiaceae. Ann Mo Bot Gard 96(1):4-26. https://doi.org/ $10.3417 / 2006197$

Bridson DM (1985) The Reinstatement of Psydrax (Rubiaceae, Subfam. Cinchonoideae Tribe Vanguerieae) and a revision of the African species. Kew Bull 40(4):687-725. https:// doi.org/10.2307/4109853

Bridson DM (1986) The Reinstatement of the African Genus Keetia (Rubiaceae Subfam. Cinchonoidedeae, Tribe Vanguerieae). Kew Bull 41(4):965-994. https://doi.org/10. 2307/4102996

Buathong R, Schindler F, Schinnerl J, Valant-Vetschera K, Bacher M, Potthast A, Rosenau T, Vajrodaya S (2019) Uncommon fatty acids, iridoids and other secondary metabolites from the medicinal plant species ixora cibdela craib (Rubiaceae). Phytochem Lett 33:77-80. https://doi. org/10.1016/j.phytol.2019.07.011

Bubonja-Šonje M, Knežević S, Abram M (2020) Challenges to antimicrobial susceptibility testing of plant-derived polyphenolic compounds. Arch Ind Hyg Toxicol 71(4):300-311. https://doi.org/10.2478/aiht-2020-71-3396

Castro SG, Cid JEV, Ibañez WAS, Alejandro GJD, Tan MA (2016) GC-MS metabolite profiling of the hexane extract and antimicrobial characterization of the Philippine endemic rubiaceae species uncaria cordata var. circa, psychotria luzoniensis, and psydrax puberula. Acta Manilana 64:9-16

Catarino L, Havik PJ, Romeiras MM (2016) Medicinal plants of guinea-bissau: therapeutic applications, ethnic diversity and knowledge transfer. J Ethnopharmacol 183:71-94. https://doi.org/10.1016/j.jep.2016.02.032
Chandramouli B, Mallikarjuna K (2020) Enumeration of various ayurvedic formulations listed in an ancient palm-leaf manuscript of Rayalaseema region in Andhra Pradesh State, India. J Ethnopharmacol 251:112552. https://doi. org/10.1016/j.jep.2020.112552

Cheek M, Sonké B (2004) Psydrax bridsoniana ( Rubiaceae ), a new species of tree from western cameroon. Kew Bull 59:605-608. https://doi.org/10.2307/4110919

Chukwujekwu JC, van Staden J, Smith P (2005) Antibacterial, anti-inflammatory and antimalarial activities of some nigerian medicinal plants. S Afr J Bot 71(3-4):316-325. https://doi.org/10.1016/S0254-6299(15)30105-8

Cos P, Vlietinck AJ, Berghe DV, Maes L (2006) Anti-infective potential of natural products: how to develop a stronger in vitro 'proof-of-concept.' J Ethnopharmacol 106(3):290-302. https://doi.org/10.1016/j.jep.2006.04.003

Coulerie P, Poullain C (2016) New caledonia: a hot spot for valuable chemodiversity part 3: santalales, caryophyllales, and asterids. Chem Biodivers 13(4):366-379. https://doi. org/10.1002/cbdv.201500101

Daanaa S, Abotsi WKM, Boakye-Gyasi E, Woode E (2018) Anticonvulsant effect of the hydroethanolic leaf extract of psydrax subcordata (DC.) bridson in murine models. J Ethnopharmacol 213:384-394. https://doi.org/10.1016/j. jep.2017.11.028

Davis AP, Govaerts R, Bridson DM (2007) New combinations in madagascan vanguerieae (Rubiaceae) for the Genera psydrax, pyrostria, and rytigynia. Blumea - Biodiversity, Evolution and Biogeography of Plants 52(1):139-145. https://doi.org/10.3767/000651907X612382

Dhivya SM, Kalaichelvi K (2016) Medicinal plants used by irula eribes of nellithurai beat, karamadai range, western ghats, tamil nadu, india: an ethnobotanical survey. Journal of Medicinal Plants Studies 4(4):270-277

Dinda, B. 2019. "Pharmacology of Iridoids." Pp. 145-254 in Pharmacology and Applications of Naturally Occuring Iridoids. Cham: Springer International Publishing.

Dutta MP, Singh MK, Borah D (2019) Piscicidal plants of northeast india and its future prospect in aquaculture-a comprehensive review. Indian $\mathrm{J}$ Nat Prod Resour 10(3):165-174

Eloff JN (2019) Avoiding pitfalls in determining antimicrobial activity of plant extracts and publishing the results. BMC Complement Altern Med 19(106):1-8. https://doi.org/10. 1186/s12906-019-2519-3

Essien E, Newby J, Walker T, Setzer W, Ekundayo O (2015) Characterization and antimicrobial activity of volatile constituents from fresh fruits of alchornea cordifolia and canthium subcordatum. Medicines 3(1):1. https://doi.org/ 10.3390/medicines3010001

Eswani N, Kudus KA, Nazre M, Awang Noor AG, Ali M (2010) Medicinal plant diversity and vegetation analysis of logged over hill forest of tekai tembeling forest reserve, Jerantut, Pahang. J Agric Sci 2(3):189-210. https://doi.org/10.5539/ jas.v2n3p189

Fan Q, Na Z, Ji K, Gongpan P, Zhou L, He W, Huang F, Huabin $\mathrm{Hu}$, Song Q (2020) A novel pentacyclic triterpene from the canes of uncaria sessilifructus (Rubiaceae). Nat Prod Res. https://doi.org/10.1080/14786419.2020.1795856

Feenna OP, Estella OU, Obodike EC (2020) Phytochemical analysis and anti-diabetic activity of leaf extract of psydrax 
horizontalis schum and thonn (Rubiaceae). Pharmacognosy Journal 12(1):95-102. https://doi.org/10.5530/pj. 2020.12.15

Gaertner, Joseph. 1788. De Fructibus Et Seminibus Plantarum. Stutgardiae: Typis Academiae Carolinae

Gemedo-Dalle T, Maass BL, Isselstein J (2005) plant biodiversity and ethnobotany of borana pastoralists in Southern Oromia, Ethiopia. Econ Bot 59(1):43-65

Gertsch J (2009) How scientific is the science in ethnopharmacology? Historical perspectives and epistemological problems. J Ethnopharmacol 122(2):177-183. https://doi. org/10.1016/j.jep.2009.01.010

Ghisalberti ELL (1998) Biological and pharmacological activity of naturally occurring iridoids and secoiridoids. Phytomedicine 5(2):147-163. https://doi.org/10.1016/S09447113(98)80012-3

Gibbons KL (2020) Hedyotis, oldenlandia and related genera (Rubiaceae: Spermacoceae) in Australia: New Genera and New Combinations in an Asian-Australian-Pacific Lineage. Taxon 69(3):515-542. https://doi.org/10.1002/tax. 12236

Goh SH, Lee KH, Chuah CH, Ong HC, Madani L, Pereira JT (1997) A phytochemical study of borneo: selected plants from sabah lowland forests. J Herbs Spices Med Plants 5(1):29-52. https://doi.org/10.1300/J044v05n01_05

Gunasegaran R, Subramani K, Azantha Parimala P, Ramachandran Nair AG, Rodriguez B, Madhusudanan KP (2001) 7-O-(6-O-Benzoyl- $\beta$-d-Glucopyranosyl)-Rutin from leaves of canthium dicoccum. Fitoterapia 72(3):201-205. https://doi.org/10.1016/S0367326X(00)00302-6

Gupta R, Sharma AK, Dobhal MP, Sharma MC, Gupta RS (2011) Antidiabetic and antioxidant potential of $\beta$-Sitosterol in streptozotocin-induced experimental hyperglycemia. J Diabetes 3(1):29-37. https://doi.org/10.1111/j. 1753-0407.2010.00107.x

Heitzman ME, Neto CC, Winiarz E, Vaisberg AJ, Hammond GB (2005) Ethnobotany, phytochemistry and pharmacology of Uncaria (Rubiaceae). Phytochemistry 66(1):5-29. https://doi.org/10.1016/j.phytochem.2004.10.022

Hussain H, Green IR, Saleem M, Raza ML, Nazir M (2019) Therapeutic potential of iridoid derivatives: patent review. Inventions 4(2):1-16. https://doi.org/10.3390/ inventions 4020029

Ilboudo DP, Basilico N, Parapini S, Corbett Y, D’Alessandro S, Dell'Agli M, Coghi P, Karou SD, Sawadogo R, Gnoula C, Simpore J, Nikiema J-B, Monti D, Bosisio E, Taramelli D (2013) Antiplasmodial and anti-inflammatory activities of canthium henriquesianum (K. Schum), a plant used in traditional medicine in burkina faso. J Ethnopharmacol 148(3):763-769. https://doi.org/10.1016/j.jep.2013.04.049

Joubouhi C, Mabou FD, Tebou FPL, Ngnokam D, Harakat D, Voutquenne-Nazabadioko L, Tebou PLF, Ngnokam D, Harakat D, Voutquenne-Nazabadioko L (2015) Five new iridoïd dimers from the fruits of canthium subcordatum DC (Syn. Psydrax Subcordata DC). Phytochem Lett 13:348-354. https://doi.org/10.1016/j.phytol.2015.07.021

Joubouhi C, Tamokou J, Ngnokam D, Voutquenne-Nazabadioko L, Kuiate J (2017) Iridoids from canthium subcordatum iso-butanol fraction with potent biological activities.
BMC Complement Altern Med 17(17):1-8. https://doi.org/ 10.1186/s12906-016-1536-8

Kala SC (2015) Medicinal attributes of family rubiaceae. International Journal Pf Pharmacy and Biological Science 5(2):179-181. https://doi.org/10.4103/0973-7847.95866

Kalaichelvi K, Dhivya SM (2016) Ethno medicinal knowledge of plants used by irula tribes of nellithurai beat, karamadai range, western ghats and phytochemical screening of selected lamiaceae species. Adv J Pharm Life Sci Res 4(2):54-64

Kalita BC, Tag H, Gogoi BJ, Hui PK (2017) Diversity and traditional uses of some poisonous plants of Arunachal Pradesh. IJARIIE 3(1):755-763

Koehbach J, Attah AF, Berger A, Hellinger R, Kutchan TM, Carpenter EJ, Rolf M, Sonibare MA, Moody JO, Wong G-S, Dessein S, Greger H, Gruber CW (2013) Cyclotide discovery in gentianales revisited-identification and characterization of cyclic cystine-knot peptides and their phylogenetic distribution in rubiaceae plants. Biopolymers 100(5):438-452. https://doi.org/10.1002/bip.22328

Lantz H, Bremer B (2004) Phylogeny inferred from morphology and DNA data: characterizing well-supported groups in vanguerieae (Rubiaceae). Bot J Linn Soc 146(3):257-283. https://doi.org/10.1111/j.1095-8339.2004.00338.x

Lantz H, Andreasen K, Bremer B (2002) Nuclear RDNA ITS sequence data used to construct the first phylogeny of vanguerieae ( Rubiaceae ). Plant Syst Evol 230:173-187. https://doi.org/10.1007/s006060200003

Ludwiczuk A, Skalicka-Woźniak K, Georgiev MII (2017) Terpenoids. Elsevier

Magassouba FBB, Diallo AKK, Kouyat'e M, Mara F, Mara O, Bangoura O, Camara A, Traor S, Diallo AKK, Zaoro M, Lamah K, Diallo S, Camara G, Traor'e S, Keita A, Camara MKK, Barry R, Keita S, Oulare K, Barry MSS, Donzo M, Camara K, Tote K, VandenBerghe D, Totte J, Pieters L, Vlietinck AJJ, Balde AM, Kouyaté M, Mara F, Mara O, Bangoura O, Camara A, Traoré S, Diallo AKK, Zaoro M, Lamah K, Diallo S, Camara G, Traoré S, Kéita A, Camara MKK, Barry R, Kéita S, Oularé K, Barry MSS, Donzo M, Camara K, Toté K, VandenBerghe D, Totté J, Pieters L, Vlietinck AJJ, Baldé AMM (2007) Ethnobotanical survey and antibacterial activity of some plants used in guinean traditional medicine. J Ethnopharmacol 114(1):44-53. https://doi.org/10.1016/j.jep.2007.07.009

Magwede K, van Wyk BEE, van Wyk AEE (2018) An Inventory of Vhavenda Useful Plants. S Afr J Bot 122:57-89. https:// doi.org/10.1016/j.sajb.2017.12.013

Mahyuni R, Chikmawati T, Ariyanti NS (2019) Short communication: two new species and new record of psydrax gaertn. (Rubiaceae: Vanguerieae) in Borneo. Biodiversitas Journal of Biological Diversity 20:2011-2015. https://doi. org/10.13057/biodiv/d200730

Maldonado C, Barnes CJ, Cornett C, Holmfred E, Hansen SH, Persson C, Antonelli A, Rønsted N (2017) Phylogeny predicts the quantity of antimalarial alkaloids within the iconic yellow cinchona bark (Rubiaceae: Cinchona Calisaya). Front Plant Sci 8:1-16. https://doi.org/10.3389/fpls. 2017.00391

Maroyi A (2012) Use of traditional veterinary medicine in nhema communal area of the Midlands Province, 
Zimbabwe. Afr J Tradit Complement Altern Med 9(3):315-322. https://doi.org/10.4314/ajtcam.v9i3.3

Memvanga PB, Tona GL, Mesia GK, Lusakibanza MM, Cimanga RK (2015) Antimalarial activity of medicinal plants from the democratic republic of congo: a review. J Ethnopharmacol 169:76-98. https://doi.org/10.1016/j. jep.2015.03.075

Mesia GK, Tona GL, Nanga TH, Cimanga RK, Apers S, Cos P, Maes L, Pieters L, Vlietinck AJ (2008) Antiprotozoal and cytotoxic screening of 45 plant extracts from democratic republic of congo. J Ethnopharmacol 115(3):409-415. https://doi.org/10.1016/j.jep.2007.10.028

Muhit MdA, Khanam SS, Islam MdS, Rahman MS, Begum B (2010) Phytochemical and biological investigations of pterospermum acerifolium wild bark. J Pharm Res 3(11):2643-2646

Mukandiwa L, Eloff JN, Naidoo V (2012a) Evaluation of plant species used traditionally to treat myiasis for activity on the survival and development of lucilia cuprina and chrysomya marginalis (Diptera: Calliphoridae). Vet Parasitol 190(3-4):566-572. https://doi.org/10.1016/j.vetpar.2012. 06.027

Mukandiwa L, Naidoo V, Eloff JN (2012b) In Vitro antibacterial activity of seven plants used traditionally to treat wound myiasis in animals in Southern Africa. J Med Plants Res 6(27):4379-4388. https://doi.org/10.5897/jmpr11. 1130

Nahrstedt A, Rockenbach J, Wray V (1995) Phenylpropanoid glycosides, a furanone glucoside and geniposidic acid from members of the rubiaceae. Phytochemistry 39(2):375-378. https://doi.org/10.1016/0031-9422(94)00906-A

Neelima M, Prasad GP, Sudarsanam G, G. P. enahala Pratap, and B. Jyothi. (2011) Ethnobotanical Studies in rapur forest division of Nellore District in Andhra Pradesh. Life Science Leaflets 11:333-345

Nyahangare ET, Mvumi BM, Mutibvu T (2015) Ethnoveterinary plants and practices used for ecto-parasite control in semi-arid smallholder farming areas of Zimbabwe. J Ethnobiol Ethnomed 11(30):1-16. https://doi.org/10.1186/ s13002-015-0006-6

Ochwang'i DO, Kimwele CN, Oduma JA, Gathumbi PK, Kiama SG, Efferth T (2016) Phytochemical screening of medicinal plants of the kakamega country, kenya commonly used against cancer. Med Aromat Plants 05(06):1-7. https://doi. org/10.4172/2167-0412.1000277

Ochwang'i DO, Kimwele CN, Oduma JA, Gathumbi PK, Mbaria JM, Kiama SG (2014) Medicinal plants used in treatment and management of cancer in Kakamega County, Kenya. J Ethnopharmacol 151(3):1040-1055. https://doi. org/10.1016/j.jep.2013.11.051

Ochwang'i DO, Kimwele CN, Oduma JA, Gathumbi PK, Kiama SG, Efferth T (2018) Cytotoxic activity of medicinal plants of the Kakamega County (Kenya) against drug-sensitive and multidrug-resistant cancer cells. J Ethnopharmacol 215:233-240. https://doi.org/10.1016/j.jep.2018.01.004

Pakkala KR, Patel HA (2021) Overview on some indigenous medicinal plants utilized in treatment of gynecological disorders by indian women. Doctrines of Integratedive Medicine, Pharmacy and Science-the International Journal 01(01):54-74
Ponnaiah J, Karthikeyan S, Tagore JK (2018) Medicinal plants used for fertility and menstrual disorders by the women belonging to the nilgiris tribe community of Southern India. International Journal of Scientific Research and Reviews 7(4):601-608

du Preez, Iwanette, Whitney Shingenge, and Davis Ropafadzo Mumbengegwi. 2020. "Namibian Plants Used in the Treatment of Malaria and Associated Symptoms." Pp. 45-66 in ACS Symposium Series. Vol. 1361. Washington, DC: American Chemical Society.

Quang BH, Tran TB, Ha TD, Van HD, Thanh HNT, Thu HB, Dang VS (2020) A New Species of Psydrax (Vanguerieae, Rubiaceae) from the Gia Lai Plateau, Southern Vietnam. PhytoKeys 149:99-107. https://doi.org/10.3897/ phytokeys.149.51710

Radol AO, Kiptoo M, Makokha AO, Tolo FM (2016) Types of herbal medicine used for HIV conditions in Vihiga County, Kenya. European Journal of Medicinal Plants 13(2):1-23. https://doi.org/10.9734/EJMP/2016/23180

Raja RN, RamaLakshmi S, Muthuchelian K (2011) GC-MS analysis of bioactive components from the ethanolic leaf extract of Canthium Dicoccum (Gaertn.) Teijsm \& Binn. J Chem Pharm Res 3(3):792-798

Rasingam L (2012) Ethnobotanical Studies on the wild edible plants of Irula Tribes of Pillur Valley, Coimbatore District, Tamil Nadu, India. Asian Pac J Trop Biomed 2(3):S1493S1497. https://doi.org/10.1016/S2221-1691(12)60443-2

Rathinavelusamy P, Mazumder PM, Sasmal D, Jayaprakash V (2014) Evaluation of in Silico, in Vitro $\alpha$-amylase inhibition potential and antidiabetic activity of pterospermum acerifolium bark. Pharm Biol 52(2):199-207. https://doi. org/10.3109/13880209.2013.823551

Ríos JL, Recio MC (2005) Medicinal plants and antimicrobial activity. J Ethnopharmacol 100(1-2):80-84. https://doi. org/10.1016/j.jep.2005.04.025

Rockenbach J, Nahrstedt A (1990) New and known Cyanogenic glycosides from the rubiaceae. Planta Med 56:591-592

Rockenbach J, Nahrstedt A, Wray V (1992) Cyanogenic glycosides from PS psydrax and oxyanthus species. Phytochemistry 31(2):567-570. https://doi.org/10.1016/00319422(92)90039-S

Schwarz B, Wray V, Proksch P (1996) A cyanogenic glycoside from canthium schimperianum. Phytochemistry 42(3):633-636. https://doi.org/10.1016/00319422(96)00018-0

Sen SK, Behera LM (2016) Some ethnomedicinal plants used against high blood pressure in bargarh district in Western Odisha (India). Tropical Plant Research 3(3):517-521. https://doi.org/10.22271/tpr.2016.v3.i3.068

Sévenet, Thierry, and Jacques Pusset. 1996. "Alkaloids from the Medicinal Plants of New Caledonia." Pp. 1-73 in Alkaloids: Chemistry and Pharmacology. Vol. 48.

Subashree K, Dar JA, Karuppusamy S, Sundarapandian S (2021) Plant diversity, structure and regeneration potential in tropical forests of Western Ghats, India. Acta Ecol Sin 41(4):259-284. https://doi.org/10.1016/j.chnaes.2020.02. 004

Tabuti JRS, Ticktin T, Arinaitwe MZ, Muwanika VB (2009) Community attitudes and preferences towards woody species: implications for conservation in nawaikoke, 
Uganda. Oryx 43(03):393-402. https://doi.org/10.1017/ S0030605309001847

Tabuti JRS, Muwanika VB, Arinaitwe MZ, Ticktin T (2011) Conservation of priority woody species on farmlands: a case study from Nawaikoke Sub-County, Uganda. Appl Geogr 31(2):456-462. https://doi.org/10.1016/j.apgeog. 2010.10 .006

Taher M, Shaari SS, Susanti D, Arbain D, Zakaria ZA (2020) Genus ophiorrhiza: a review of its distribution, traditional uses, phytochemistry, biological activities and propagation. Molecules 25(11):2611. https://doi.org/10.3390/ molecules 25112611

Tan HP, Wong DZH, Ling SK, Chuah CH, Kadir HA (2012) Neuroprotective activity of galloylated cyanogenic glucosides and hydrolysable tannins isolated from leaves of phyllagathis rotundifolia. Fitoterapia 83(1):223-229. https://doi.org/10.1016/j.fitote.2011.10.019

Tilney PM, van Wyk AE, Kok PDF (1988) The taxonomic significance of anatomical characters of the stem in the Southern African Species of Canthium s.l. (Rubiaceae). S Afr J Bot 54(6):585-595. https://doi.org/10.1016/s02546299(16)31258-3

Tilney PM, Kok PDF, van Wyk AE (1990) The taxonomic significance of anatomical characters of the leaf in the Southern African Species of Canthium s.l. (Rubiaceae). S Afr J Bot 56(3):363-382. https://doi.org/10.1016/s02546299(16)31066-3

Tundis R, Loizzo M, Menichini F, Statti G, Menichini F (2008) Biological and pharmacological activities of iridoids: recent developments. Mini-Rev Med Chem 8(4):399-420. https://doi.org/10.2174/138955708783955926

Umaiyambigai, D., K. Saravanakumar, and G. A. Raj. 2016. "Phytochemical Profiles, Antibacterial and Antifungal
Activity of Leaves from the Psydrax Dicoccos (Gaertn)." Indo - Asian Journal of Multidisciplinary Research ( IAJMR ) 2(1):443-52.

Vaidyanathan D, Salai Senthilkumar MS, Ghouse Basha M (2013) Studies on ethnomedicinal plants used by malayali Tribals in Kolli Hills of Eastern Ghats, Tamilnadu, India. Asian Journal of Plant Science and Research 3(6):29-45

Vijayashalini P, Anjanadevi N, Abirami P, Sharmila M (2017) Ethnomedicinal plants survey in Elanji Hill Village sathyamangalam range of reserve forest, Western Ghats Tamil Nadu India. Int J Biol Res 2(1):22-26

Wijnsma, R., and R. Verpoorte. 1986. "Anthraquinones in the Rubiaceae." Pp. 79-149 in Progress in the Chemistry of Organic Natural Products.

Yang B, Feng YJ, Hoan Vu, McCormick B, Rowley J, Pedro L, Crowther GJ, Van Voorhis WC, Forster PI, Quinn RJ (2016) Bioaffinity mass spectrometry screening. J Biomol Screen 21(2):194-200. https://doi.org/10.1177/ 1087057115622605

Yulvianti M, Zidorn C (2021) Chemical diversity of plant cyanogenic glycosides: an overview of reported natural products. Molecules 26(3):719. https://doi.org/10.3390/ molecules 26030719

Zhou J, Zhenlong Wu, Oyawaluja BO, Coker HAB, Odukoya OA, Yao G, Che C-T (2019) Protein tyrosine phosphatase $1 B$ inhibitory iridoids from psydrax subcordata. J Nat Prod 82(10):2916-2924. https://doi.org/10.1021/acs.jnatprod. $9 \mathrm{~b} 00770$

Publisher's Note Springer Nature remains neutral with regard to jurisdictional claims in published maps and institutional affiliations. 